\title{
Toxicity assessment of zinc oxide nanoparticles using sub-acute and sub-chronic murine inhalation models
}

Andrea Adamcakova-Dodd ${ }^{1}$, Larissa V Stebounova², Jong Sung Kim', Sabine U Vorrink' , Andrew P Ault ${ }^{2}$, Patrick T O'Shaughnessy', Vicki H Grassian² and Peter S Thorne ${ }^{1 *}$

\begin{abstract}
Background: Although ZnO nanoparticles (NPs) are used in many commercial products and the potential for human exposure is increasing, few in vivo studies have addressed their possible toxic effects after inhalation. We sought to determine whether ZnO NPs induce pulmonary toxicity in mice following sub-acute or sub-chronic inhalation exposure to realistic exposure doses.

Methods: Mice (C57Bl/6) were exposed to well-characterized ZnO NPs ( $3.5 \mathrm{mg} / \mathrm{m}^{3}, 4 \mathrm{hr} /$ day) for 2 (sub-acute) or 13 (sub-chronic) weeks and necropsied immediately ( 0 wk) or 3 weeks ( 3 wks) post exposure. Toxicity was assessed by enumeration of total and differential cells, determination of total protein, lactate dehydrogenase activity and inflammatory cytokines in bronchoalveolar lavage (BAL) fluid as well as measurements of pulmonary mechanics. Generation of reactive oxygen species was assessed in the lungs. Lungs were evaluated for histopathologic changes and Zn content. Zn concentration in blood, liver, kidney, spleen, heart, brain and BAL fluid was measured.

Results: An elevated concentration of $\mathrm{Zn}^{2+}$ was detected in BAL fluid immediately after exposures, but returned to baseline levels 3 wks post exposure. Dissolution studies showed that ZnO NPs readily dissolved in artificial lysosomal fluid (pH 4.5), but formed aggregates and precipitates in artificial interstitial fluid (pH 7.4). Sub-acute exposure to ZnO NPs caused an increase of macrophages in BAL fluid and a moderate increase in IL-12(p40) and MIP-1a, but no other inflammatory or toxic responses were observed. Following both sub-acute and sub-chronic exposures, pulmonary mechanics were no different than sham-exposed animals.

Conclusions: Our ZnO NP inhalation studies showed minimal pulmonary inflammation, cytotoxicity or lung histopathologic changes. An elevated concentration of $\mathrm{Zn}$ in the lung and BAL fluid indicates dissolution of $\mathrm{ZnO}$ NPs in the respiratory system after inhalation. Exposure concentration, exposure mode and time post exposure played an important role in the toxicity of ZnO NPs. Exposure for 13 wks with a cumulative dose of $10.9 \mathrm{mg} / \mathrm{kg}$ yielded increased lung cellularity, but other markers of toxicity did not differ from sham-exposed animals, leading to the conclusion that ZnO NPs have low sub-chronic toxicity by the inhalation route.
\end{abstract}

Keywords: Zinc oxide nanoparticles, Dissolution, Inhalation, Murine model, Pulmonary response, Toxicity

\footnotetext{
*Correspondence: peter-thorne@uiowa.edu

'Department of Occupational and Environmental Health, University of lowa, lowa City, IA 52242, USA

Full list of author information is available at the end of the article
} 


\section{Introduction}

Materials engineered at the nanoscale currently exist in over a thousand consumer products including cosmetics, electronics, medical devices, and textiles [1]. Metal and metal oxide nanoparticles (NPs) are also under development for antimicrobial, self-decontaminating and UV blocking functions for both military protection gear and civilian health products. $\mathrm{Ag}, \mathrm{TiO}_{2}, \mathrm{ZnO}$, and $\mathrm{CeO}_{2}$ are among the nanomaterials most widely incorporated into market goods. Zinc oxide $(\mathrm{ZnO}) \mathrm{NPs}$ are used in various product categories because of their unique photocatalytic, electronic, optical, dermatological, and antibacterial properties; however the most common applications are in sunscreens [2], baby powders, antidandruff shampoos, and fabric treatments for UV shielding $[3,4]$. Welding fumes, especially from galvanized steel, can also be source of exposure to $\mathrm{ZnO}$ aerosol in the nanometer range [5,6]. Additionally, ZnO NPs have received more attention due to their putative anti-cancer properties and for drug delivery [7].

Most of the production processing takes place within closed systems, however during postproduction and packaging, $\mathrm{ZnO}$ NPs may be released into the ambient air where they circulate for some time. During this time there is a potential for worker and public exposure via inhalation [2]. With increasing interest to their potential toxicity, adverse effects of ZnO NPs have been recently studied in vivo [8-13] and in vitro [14-21]. However, despite the growing literature on nanomaterials applications, the information about biological effects of $\mathrm{ZnO}$ NPs is still insufficient and often controversial. Many reports using in vitro systems indicate that the mechanism of $\mathrm{ZnO}$ toxicity involves the generation of reactive oxygen species (ROS) $[15,16,18,22]$. Some report that dissolution of $\mathrm{ZnO}$, which is enhanced for the smallest particles [23] plays an important role in the toxicity mechanism of $\mathrm{ZnO}$ NPs $[18,19,22]$. It has been shown that $\mathrm{ZnO}$ dissociation disrupts cellular zinc homeostasis in mouse leukemic monocyte macrophage cells (RAW 264.7), leading to lysosomal and mitochondria damage and ultimately cell death [22]. Another in vitro study indicated that free $\mathrm{Zn}^{2+}$ ions are not a major contributor of ROS generation [16]. The release of ions from $\mathrm{ZnO}$ NPs in biological media depends on many factors, such as $\mathrm{pH}$, ligands present in the solution, surface groups, or impurities [11]. Because of these effects, it can be lower or higher than predicted from aqueous phase thermodynamic behavior of $\mathrm{ZnO}$ alone [18]. A limitation of the above-referenced studies is that the nanoparticle dose used usually exceeds an environmentally relevant dose. Moreover, these in vitro models cannot replicate the intact cardiovascular system and various cellular interactions present in the body. Hence, in vitro models fall short of accurately predicting the toxicological behavior of the nanoparticles in living organisms, especially if studied in submersed conditions when particles are suspended in media [24] which can impact dispersion and dissolution.

More recently, there is an increasing body of literature reporting on $\mathrm{ZnO} \mathrm{NP}$ toxicity studies in vivo [8-12,25]. An oral exposure of mice to 20 and $120 \mathrm{~nm}$ particles indicated minimal toxicity of $\mathrm{ZnO}$ NPs, where smaller NPs were slightly more toxic than the larger ones [9]. Some pathological damage was observed in gastric, liver, heart and spleen in this oral toxicity study. Pulmonary toxicity has been assessed in instillation $[8,11,12,26]$ and inhalation exposure [10] models. Instillation studies in rodents have shown that $\mathrm{ZnO}$ NPs are capable of inducing acute pulmonary inflammation, including neutrophil recruitment and lactate dehydrogenase (LDH) release at cumulative doses of $0.6 \mathrm{mg} / \mathrm{kg}$ [11] and $5 \mathrm{mg} / \mathrm{kg}$ [12]. Moreover, it has been suggested that metal oxide NPs may produce unique inflammatory footprints in the lung depending on the metal content and a propensity to deliver soluble ions [8]. ZnO NPs exhibited eosinophilic inflammation without cytotoxicity in the rat instillation exposure study by Cho et al. [8]. A decreased dissolution of $\mathrm{ZnO}$ NPs by iron doping reduced pulmonary inflammation in another oropharyngeal and intratracheal instillation rat study [11].

In order to better understand, and potentially resolve, disparate findings from in vivo instillation studies and in vitro studies, we exposed male $\mathrm{C} 57 \mathrm{Bl} / 6$ mice to fully characterized commercially available ZnO NPs by inhalation in a whole-body inhalation chamber for periods of 2 or 13 wks. The potential toxic effects associated with the inhalation of $\mathrm{ZnO}$ NPs were assessed in mice with evaluation of lung inflammation, cytotoxicity, oxidative stress, pulmonary mechanics with methacholine challenge and hematology parameters. Body burden of zinc in the lungs, blood and other selected tissues was measured.

\section{Materials and methods}

\section{Nanomaterial bulk properties characterization}

Zinc oxide NPs with stated primary particle average diameter of $10 \mathrm{~nm}$ were purchased in two different lots (Meliorum Technologies, Inc. Rochester, NY) and used as received. Powder X-ray diffraction (XRD) was performed using Bruker D-5000 q - q X-ray diffractometer with Kevex-sensitive detector (Madison, WI) to identify crystalline phases present in the sample. We assessed the primary particle size of 400 random $\mathrm{ZnO}$ NPs by transmission electron microscopy (TEM) (JEOL JEM-1230, Japan) to evaluate the veracity of the manufacturer's specifications, as well as to image the NPs aerosols generated in the inhalation exposure chamber. 
Surface area and surface composition of the $\mathrm{ZnO}$ NPs were measured. For surface area measurements, an automated multipoint BET surface area apparatus (Quantachrome Nova 4200e, Boynton Beach, FL) using nitrogen gas as the adsorbent was used. Samples were degassed at $100^{\circ} \mathrm{C}$ for $12 \mathrm{hr}$ under vacuum prior to the analysis. Surface composition was characterized using attenuated total reflectance (ATR) Fourier transform infrared (FTIR) spectroscopy equipped with a MCT/A detector (Thermo Scientific Nicolete FTIR spectrometer, Waltham, MA). For these measurements, a thin, evenly coated $\mathrm{ZnO}$ film was deposited onto an AMTIR (amorphous material transmitting infrared radiation) crystal element in a horizontal ATR cell (Pike Technologies, Inc.). The film was prepared by placing a suspension of $\mathrm{ZnO} \mathrm{NPs}(1 \mathrm{mg} / \mathrm{mL}$ in Optima water) onto the crystal and drying overnight. X-ray photoelectron spectroscopy (XPS) was used to probe the surface chemical composition of the powdered sample (Ultra-Axis XPS, Kratos, Manchester, UK) as previously described [27].

\section{Dissolution measurements}

Dissolution of ZnO NPs was measured in simulated biological fluids including artificial lysosomal fluid (ALF) $(\mathrm{pH}=4.5)$ and Gamble's solution $(\mathrm{pH}=7.4)$ using inductively coupled plasma optical emission spectroscopy (ICP-OES) (Varian 720 ES, Walnut Creek, CA) as previously described [28]. The ALF fluid simulates the phagolysosomal composition and $\mathrm{pH}$ of alveolar and interstitial macrophages and the Gamble's solution is used to mimic the interstitial fluid in the lungs.

\section{Animals}

Inhalation exposure studies followed the same experimental design as in several of our previous studies [28-30]. Mice (C57Bl/6, males, 5 wks old, The Jackson Laboratory, Bar Harbor, ME) were acclimatized for 12 days before exposure while housed in our vivarium in polypropylene, fiber-covered cages in HEPA-filtered Thoren caging units (Hazelton, PA). Food (sterile Teklad 5\% stock diet, Harlan, Madison, WI) and water (via an automated watering system) were provided ad libitum. Light-dark cycle (12 hr) was maintained in the animal room. All protocols were approved by the Institutional Animal Care and Use Committee at the University of Iowa.

Animals without restraint were exposed by inhalation for $4 \mathrm{hr} /$ day, 5 days/wk for period of 2 wks in the subacute study and for $13 \mathrm{wks}$ in the sub-chronic study. In both studies, mice were necropsied either within one hr (0 wk) or 3 wks after (3 wks) the last exposure. During the 3 wk period post exposure, animals remained in the vivarium without exposure. Both studies also included sentinel mice that were housed in the vivarium during the whole duration of each study. The average mass concentration of $\mathrm{ZnO}$ NPs in the whole-body chamber in sub-acute study was $3.6 \pm 0.5 \mathrm{mg} / \mathrm{m}^{3}$ (mean \pm standard deviation) and in the sub-chronic study was $3.3 \pm$ $0.6 \mathrm{mg} / \mathrm{m}^{3}$. Control animals (shams) were exposed to HEPA-filtered laboratory air in the identical exposure chamber in an adjacent laboratory. We estimated cumulative doses of 51 and $306 \mu \mathrm{g} /$ mouse (in sub-acute and sub-chronic study, respectively) assuming a minute volume of $25 \mathrm{~mL} / \mathrm{min}$ and a deposition fraction of 0.24 in the tracheobronchial and pulmonary region. Deposition fraction was based on a rat computational fluid dynamic model [31] and an average particle size (40 nm) as measured by a scanning mobility particle sizer (SMPS).

\section{Generation of aerosol and inhalation exposure of mice}

Mice in this study were exposed in a whole-body exposure chamber, as previously described [32]. ZnO aerosols were generated from a suspension of $\mathrm{ZnO}$ NPs in water (Optima grade, Fisher Scientific, Pittsburgh, PA) from a liquid concentration of $1 \mathrm{mg} \mathrm{ZnO} \mathrm{NPs} / \mathrm{mL}$ using a 6-jet Collison nebulizer (BGI Inc. Waltham, MA) supplied with filtered pressurized air. To minimize agglomeration, a suspension of $\mathrm{ZnO}$ NPs in water was prepared freshly each day and ultra-sonicated (continuous sonication) with a high frequency probe set at $30 \%$ of the maximum amplitude at $20 \mathrm{kHz}$ (model 550, Fisher Scientific, Pittsburgh, PA) for 20 minutes before it was placed into the nebulizer. Most of our practices for ultrasonic dispersion of NP suspension were in an agreement with recommendations by Taurozzi et al. [33]. A magnetic stir bar was placed into the nebulizer to facilitate stirring of the $\mathrm{ZnO}$ suspension during nebulization. Aerosol generated by the nebulizer passed through a brass drying column heated to $110^{\circ} \mathrm{C}$ (to evaporate water droplets) as well as a tube containing a $20 \mathrm{mCi}{ }^{63} \mathrm{Ni}$ source (to remove static charge) prior to entering the chamber.

To assess the size distribution of generated $\mathrm{ZnO} N P$ aerosol during animal exposure, the air from the chamber was sampled at flow $1 \mathrm{~L} / \mathrm{min}$ using an SMPS (TSI Inc., Shoreview, MN, model 3036 with model 3081 longdifferential analyzer and model 3785 water-based condensation particle counter, measuring particle diameters in 105 size channels between 7.4 - $289 \mathrm{~nm}$ ). Geometric mean (GM) mobility diameter and geometric standard deviation (GSD) of aerosol sizes in individual exposures were calculated.

Mass concentration of the aerosol in the whole-body chamber was measured gravimetrically using 47-mm fiberglass filters (Whatman, Middlesex, UK) held in stainless steel holders placed in line with the exhaust air flow $(24 \mathrm{~L} / \mathrm{min})$. Filters were pre- and post-weighed using a calibrated Mettler MT5 six-place balance (Mettler-Toledo, Inc., Columbus, $\mathrm{OH}$ ) placed in a dedicated climate-controlled room and were changed every two hours. Generated aerosol in the chamber was 
collected on nickel grids placed inside the exposure chamber or using an electrostatic precipitator (Model 100, ESP Nano Inc., Spokane WA).

\section{Bronchoalveolar lavage fluid and blood analyses}

Euthanasia of mice was performed by overdose of isoflurane followed by cervical dislocation and exsanguination through the heart. The lungs $(n=6$ in each experimental group) were lavaged, in situ, 3 times with approximately $1 \mathrm{~mL}$ of $0.9 \%$ sterile sodium chloride solution (Baxter, Deerfield, IL), the recovered bronchoalveolar lavage (BAL) fluid was centrifuged $(800 \times \mathrm{g}, 5 \mathrm{~min})$, the cell pellet was used for enumeration of total and differential cell counts. The lavage supernatants were stored at $-80^{\circ} \mathrm{C}$ for later analyses of total protein using Bradford protein assay (Bio-Rad Laboratories, Inc., Hercules, CA), LDH activity (Roche Diagnostics, Penzberg, Germany) and cytokine levels measured by multiplexed fluorescent bead-based immunoassays (Bio-Plex Pro Mouse Cytokine, Chemokine, and Growth Factor Multiplex Assays, Bio-Rad Laboratories, Inc., Hercules, CA). Measured cytokines in both studies included: interleukin (IL)-6, IL-12 (p40), tumor necrosis factor (TNF)- $\alpha$, granulocyte macrophage colony stimulating factor (GM-CSF), keratinocytederived cytokine $(\mathrm{KC})$, monocyte chemotactic protein (MCP)-1, and macrophage inflammatory protein (MIP)- $1 \alpha$. In sub-chronic study, we also measured IL-4, IL-5, IL-13 and IL-17. Blood samples for analyses of hematology parameters ( $n=6$ in each group) were collected by cardiac puncture into tubes containing EDTA (Multivette, SARSTEDT AG \& Co., Nümbrecht, Germany) and analyzed using an automated hematology analyzer (Sysmex XT2100, Kobe, Japan).

\section{Lipid peroxidation assay}

To investigate the $\mathrm{ZnO} \mathrm{NP}$-mediated generation of ROS after sub-chronic exposure to $\mathrm{ZnO} \mathrm{NPs}$, malondialdehyde (MDA, product of lipid peroxidation) levels were measured in lung tissue homogenates $(n=6)$ using the thiobarbituric acid reactive substances (TBARS) assay kit (Cayman Chemical Company, Ann Arbor, MI) following the manufacturer's protocol.

\section{ICP-MS elemental analysis of BAL fluid and organs}

Cell-free BAL supernatants were centrifuged at 44,900 $\times$ $\mathrm{g}$ for $30 \mathrm{~min}$ and $\mathrm{Zn}^{2+}$ concentrations were determined. Lung, liver, spleen, kidney, heart and brain tissues from mice in each group were stored at $-80^{\circ} \mathrm{C}$ immediately after resection. Tissues were lyophilized for $16 \mathrm{hr}$ at 0.13 $\mathrm{mBar}$ and $-50^{\circ} \mathrm{C}$ in a freeze dryer (Labconco Corp., Kansas City, MO) and then weighed. The tissues were digested in a HotBlock ${ }^{\mathrm{Tw}}$ digestion system (Environmental Express, Mt. Pleasant, SC) at $95-98^{\circ} \mathrm{C}$ using mixtures of high purity concentrated hydrochloric acid and nitric acid (Fisher Optima ${ }^{\circ}$ grade) in 1:3 ratio, respectively. Metal analysis of the digested tissues, blood and BAL fluid was performed using inductively coupled plasma mass spectrometer (Xseries 2 quadrupole ICP-MS, Thermo Fisher Scientific Inc., West Palm Beach, FL) with a method detection limit for $\mathrm{Zn}$ of less than $1 \mu \mathrm{g} / \mathrm{kg}$. Each sample was spiked with cobalt as an internal standard at $20 \mu \mathrm{g} / \mathrm{L}$.

\section{Pulmonary mechanics measurements}

Airway hyper-reactivity to methacholine challenge in mice after exposure to $\mathrm{ZnO}$ nanoparticle aerosol $(\mathrm{n}=6$ in sub-acute study, $\mathrm{n}=8$ at $0 \mathrm{wk}$ and $\mathrm{n}=3$ at $3 \mathrm{wks}$ post exposure in sub-chronic study) was assessed using a forced oscillation technique in the FlexiVent system (SCIREQ, Montreal, QC, Canada). Anesthesia was induced by intraperitoneal administration of $90 \mathrm{mg} / \mathrm{kg}$ of pentobarbital sodium (Ovation Pharmaceuticals, Inc. Deerfield, IL, USA). The trachea was exposed and tracheotomy performed using a tracheal cannula with luer adapter $(1.3 \mathrm{~mm}$, length $20 \mathrm{~mm}$, Harvard Apparatus, Holliston, MA, USA). The cannula was connected to a computer-controlled small animal ventilator set at a frequency of 150 breaths/min, a tidal volume of $10 \mathrm{~mL} /$ $\mathrm{kg}$, and a positive end-expiratory pressure of 2 to $3 \mathrm{~cm}$ $\mathrm{H}_{2} \mathrm{O}$. After measurement of a baseline, each mouse was challenged with increasing concentrations of methacholine aerosol $(1,3,10$, and $30 \mathrm{mg} / \mathrm{mL})$ that were generated for $10 \mathrm{~s}$ with an in-line nebulizer directly through the canulated trachea. Dynamic resistance ( $R$ ) and dynamic compliance $(C)$ were measured using a "snapshot" protocol each $20 \mathrm{~s}$ for $5 \mathrm{~min}$, ensuring that measured parameters stabilized. The mean of these 15 values was calculated for each methacholine dose. After each dose, the lungs were inflated to total lung capacity to return the measurements to baseline.

\section{Histopathology of lung tissues}

Mice that were not lavaged $(\mathrm{n}=5$ and $\mathrm{n}=6$ in sub-acute and sub-chronic study, respectively) were perfused through the heart with saline and lungs were fixed in 10\% buffered formalin via the cannulated trachea. The tissues were paraffin-embedded, sectioned at $5 \mu \mathrm{m}$, and stained with hematoxylin and eosin (H\&E). Tissue sections were evaluated by a board-certified veterinary pathologist using light microscopy with the focus on parenchymal architecture (bronchioles, alveoli, pleura, and vasculature), and presence or absence of inflammatory cell infiltrates, evidence of acute lung injury, lymphoid agglomerates or fibrosis. We also evaluated BAL cells and lung tissues using dark field microscopy as well as TEM equipped with an energy dispersive spectrometer (EDS), as described previously [28]. 


\section{Statistical analyses}

Outcome measures from mice exposed to ZnO NPs and control mice exposed to filtered laboratory air were analyzed using one-way analyses of variance (ANOVA) followed by Tukey test (Sigma Plot v.11.0, Systat Software Inc., Point Richmond, CA). If data were not normally distributed, Kruskal-Wallis ANOVA on Ranks was used. A $p$-value less than 0.05 was considered statistically significant. Data are expressed as mean \pm standard error (SE) unless otherwise noted.

\section{Results}

\section{ZnO nanoparticle characterization}

The XRD pattern for the $\mathrm{ZnO}$ NPs are compared to standard crystalline zincite in Figure 1A. These data show that the nanoparticles have the same crystal structure as that of bulk zincite. Figure $1 \mathrm{~B}$ shows a TEM image of nanoparticle agglomerates deposited on a TEM grid from a methanol solution. The diameters of individual particles were assessed by measurement of over 400 particles and yielded a primary particle size distribution of $15 \pm 4 \mathrm{~nm}$ and $26 \pm 11 \mathrm{~nm}$ for the two lots of NPs used in sub-acute and sub-chronic study, respectively (Figure $1 \mathrm{C}$ and Table 1).

The specific surface area of the sample was calculated in the nitrogen relative pressure range from 0.05 to 0.3 where the BET isotherm is most linear. This yielded a surface area of $47 \pm 1 \mathrm{~m}^{2} / \mathrm{g}$ for ZnO NPs for the batch of NPs used in sub-acute study and $15 \pm 4 \mathrm{~m}^{2} / \mathrm{g}$ for the batch used in sub-chronic study. Surface composition examination using ATR-FTIR spectroscopy (Figure 2A) revealed that carbonates are present on the nanoparticle surface. XPS was also used to characterize the surface composition of the ZnO NPs. High resolution XPS spectra (Figures 2B) show binding energy peaks in the $\mathrm{Zn} \mathrm{2p}, \mathrm{C} 1 \mathrm{~s}$, and $\mathrm{O} 1 \mathrm{~s}$ regions of the photoelectron spectrum. The $\mathrm{Zn} 2 \mathrm{p}$ peaks at $1021.1 \mathrm{eV}$ and $1044.4 \mathrm{eV}$ (Figure 2B) can be assigned to $\mathrm{Zn}^{2+}$ in $\mathrm{ZnO}$ crystal [34]. The $\mathrm{O} 1 \mathrm{~s}$ peak positions at $530 \mathrm{eV}$ and $531.5 \mathrm{eV}$ (Figure 2B) correspond to surface and near surface oxygen in crystal lattice and $\mathrm{O}-\mathrm{H}$ groups on the surface [35]. The $C 1$ s region has three peaks (Figure 2). The peak at $285.0 \mathrm{eV}$ is due to adventitious carbon on the nanoparticle surfaces. Two species, $\mathrm{C}-\mathrm{OH}$ (hydroxyl) and $\mathrm{C}-\mathrm{O}-\mathrm{C}$ (ether), can contribute to the $286.4 \mathrm{eV}$ peak
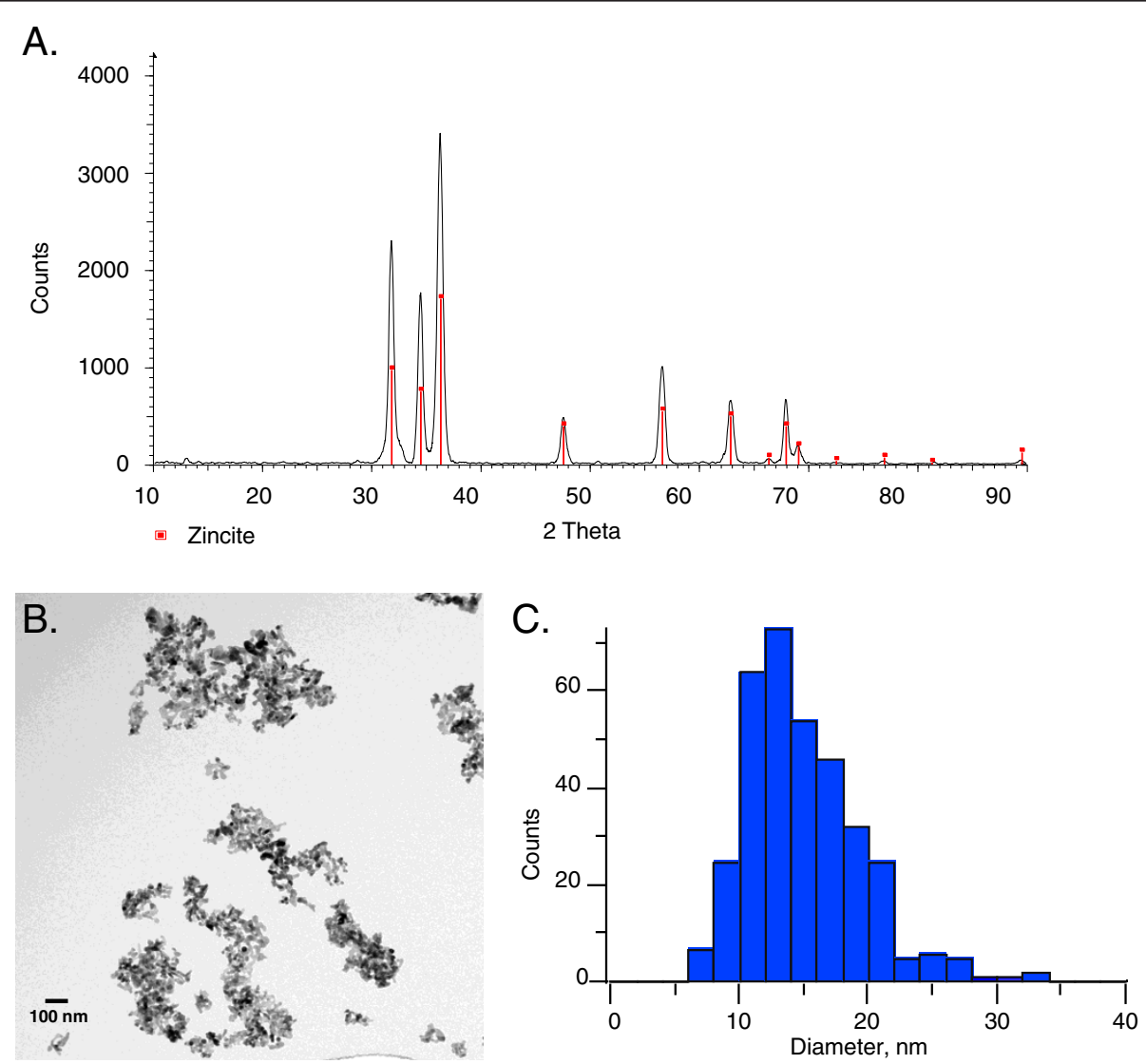

Figure 1 Characterization of the phase and size of $\mathrm{ZnO}$ nanoparticles. A. XRD spectrum pattern of the nanoparticles (black) compared to XRD spectrum of reference material, zincite (red lines). B. TEM image of ZnO nanoparticles deposited onto a TEM grid from a methanol solution. C. Particle size distribution determined from TEM. 
Table 1 Summary of physicochemical properties of $\mathrm{ZnO}$ NPs and generated aerosol

\begin{tabular}{|c|c|c|}
\hline & \multicolumn{2}{|c|}{ ZnO NPs } \\
\hline Primary particle size ${ }^{1}$ & \multicolumn{2}{|c|}{$15 \pm 4 \mathrm{~nm}(26 \pm 11 \mathrm{~nm})^{\#}$} \\
\hline Crystalline or amorphous & \multicolumn{2}{|c|}{ Crystalline, zincite } \\
\hline Surface functionality & \multicolumn{2}{|c|}{$\mathrm{CO}_{3}{ }^{2-}, \mathrm{OH}^{-}, \mathrm{CH}$} \\
\hline BET surface area ${ }^{2}$ & \multicolumn{2}{|c|}{$47 \pm 1 \mathrm{~m}^{2} / \mathrm{g}\left(15 \pm 4 \mathrm{~m}^{2} / \mathrm{g}\right)^{\#}$} \\
\hline \multirow[t]{2}{*}{ Nanoparticle dissolution } & \multicolumn{2}{|c|}{ Gamble's solution $(\mathrm{pH} 7.4):<1 \%$} \\
\hline & \multicolumn{2}{|c|}{$\mathrm{ALF}^{*}(\mathrm{pH} 4.5): 100 \%$} \\
\hline \multicolumn{3}{|c|}{ Aerosol characterization in the whole-body exposure chamber: } \\
\hline & Sub-acute study & Sub-chronic study \\
\hline \multirow[t]{2}{*}{ Aerosol size distribution ${ }^{3}$} & $\mathrm{GM}=46 \mathrm{~nm}$ & $\mathrm{GM}=36 \mathrm{~nm}$ \\
\hline & $\mathrm{GSD}=1.8$ & $\mathrm{GSD}=1.8$ \\
\hline Exposure mass concentration ${ }^{2}$ & $3.6 \pm 0.5 \mathrm{mg} / \mathrm{m}^{3}$ & $3.3 \pm 0.6 \mathrm{mg} / \mathrm{m}^{3}$ \\
\hline
\end{tabular}

[36] and the peak at $289.6 \mathrm{eV}$ is due to $\mathrm{O}-\mathrm{C}-\mathrm{O}$ (carbonate) [37].

\section{Dissolution of $\mathrm{ZnO}$ in artificial lung fluids}

Dissolution is a surface phenomenon and the propensity of $\mathrm{ZnO}$ nanoparticles to dissolve into ions was investigated. As shown in Figure 3, less than 1\% of $\mathrm{ZnO}$ dissolved in Gamble's buffer after 2 wks. In contrast, $100 \%$ of the $\mathrm{ZnO}$ dissolved within the first $24 \mathrm{hr}$ of mixing in ALF solution. ALF buffer contains $0.11 \mathrm{M}$ concentration of citric acid, which simulates in vivo protein binding. Thus this result agrees with what is known about citric acid and the ability for it to adsorb to the surface thereby promoting dissolution of $\mathrm{ZnO}$ [23]. Gamble's solution contains a much smaller amount of sodium citrate $(0.4 \mathrm{mM})$ and a complex mixture of other anions and cations that could prevent NPs from releasing $\mathrm{Zn}^{2+}$, or could trap the released ions if other precipitates form. The presence of a significant amount of citrate ions (or protein binding) affects the fate and possible toxic effect of this nanomaterialas has been extensively discussed in the literature [38]. This should be taken into account when evaluating the toxicity of $\mathrm{ZnO}$ NPs.

\section{Aerosol characterization}

$\mathrm{ZnO}$ nanoparticle aerosols collected in the exposure chamber were imaged using TEM and size distributions were measured using a SMPS (Figure 4). It can be seen that these substrate-collected aerosols contain primary particles of $\mathrm{ZnO}$ that are aggregated to form the larger aerosol. The aerosol size distribution measured in the whole-body inhalation chamber yielded a geometric mean mobility diameter of $46 \mathrm{~nm}(\mathrm{GSD}=1.8)$ and $36 \mathrm{~nm}(\mathrm{GSD}$ $=1.8$ ) in sub-acute and sub-chronic studies, respectively

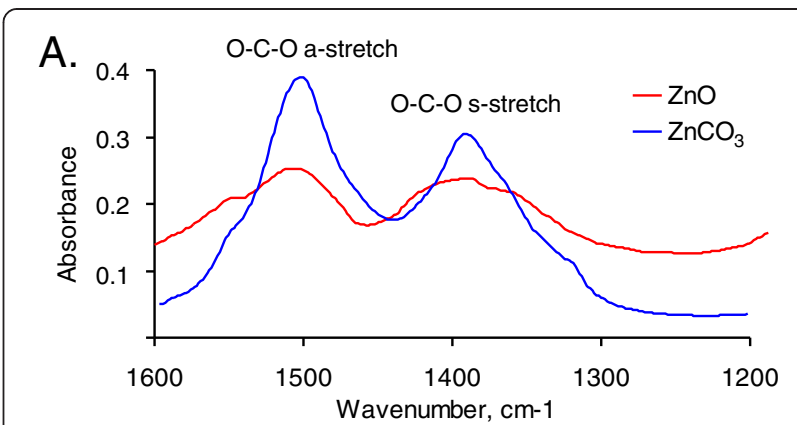

B.
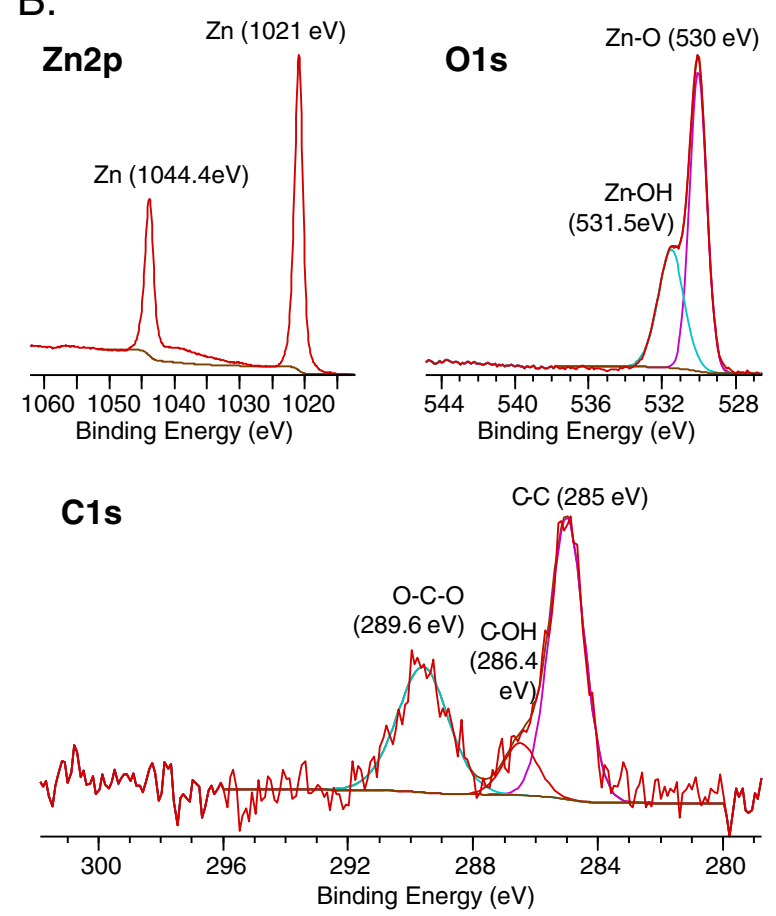

Figure $\mathbf{2}$ Characterization of surface composition for commercially manufactured ZnO NPs using spectroscopic probes. A. ATR-FTIR spectra of ZnO NPs compared to $\mathrm{ZnCO}_{3}$ in the 1200 to $1600 \mathrm{~cm}^{-1}$ region. B. High resolution XPS data of ZnO NPs in the Zn 2p, O 1s and C 1s binding energy regions.

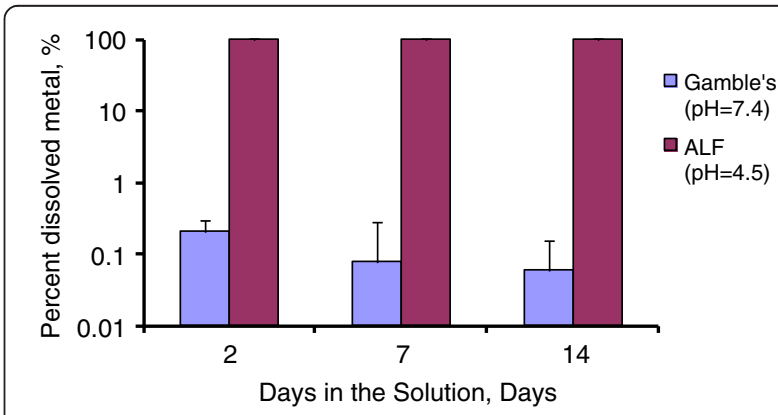

Figure 3 Dissolution of ZnO NPs in simulated biological fluids, Gamble's (pH 7.4) and ALF ( $\mathrm{pH} \mathrm{4.5)} \mathrm{solutions.} \mathrm{The} \mathrm{Y-axis} \mathrm{is}$ plotted on a logarithmic scale for clarity. 


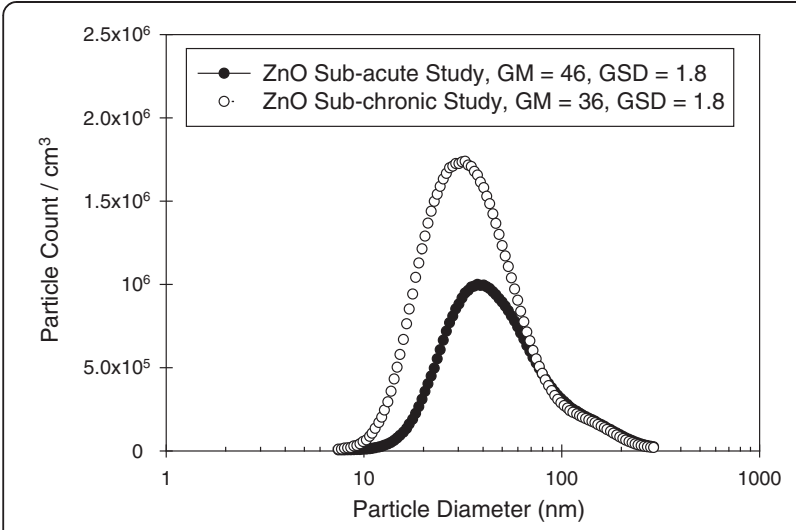

Figure 4 Particle size distributions of generetated $\mathrm{ZnO}$ aerosol measured by SMPS in sub-acute and sub-chronic studies.

(Table 1). These measurements show that the mice were exposed to aggregates in the nanoscale regime below $100 \mathrm{~nm}$. TEM-EDS analyses of particles deposited on the grids placed in the exposure chamber confirmed the presence of elemental $\mathrm{Zn}$ (data not shown).

\section{Dosimetry of ZnO NPs in the blood, BAL fluid and selected tissues}

In the sub-acute study, $\mathrm{Zn}$ lung concentrations measured by ICP-MS were significantly $(p<0.02)$ higher in mice necropsied immediately (0 wk) after the exposure $(144.8 \pm 6.9 \mu \mathrm{g} / \mathrm{g}$ lung (dry wt)) than in sham-exposed mice $(123.3 \pm 2.6 \mu \mathrm{g} / \mathrm{g}$ lung (dry wt)). Concentration of $\mathrm{Zn}$ in the lungs of mice necropsied after the 3-wk rest period ( $3 \mathrm{wks}$ ) post exposure was $131.4 \pm 13.7 \mu \mathrm{g} / \mathrm{g}$ lung (dry wt) (Table 2 ). $\mathrm{Zn}^{2+}$ concentrations in BAL fluid were significantly $(p<0.001)$ elevated immediately after the exposure $(73 \pm 9 \mu \mathrm{g} / \mathrm{L})$ compared to sham-exposed $(16 \pm 2 \mu \mathrm{g} / \mathrm{L})$ and mice rested for $3 \mathrm{wks}(16 \pm 2 \mu \mathrm{g} / \mathrm{L})$ (Table 2). Blood, liver, spleen, kidney, heart and brain did not show any significant increase of $\mathrm{Zn}$ concentration with the exposure.

In the sub-chronic study, $\mathrm{Zn}$ concentrations in BAL fluid, blood, spleen, and kidneys were elevated in the group sacrificed immediately post exposure compared to controls, but this increase was not statistically significant (Table 2). Zinc in hearts in the group at 0 wk post exposure was significantly $(p<0.05)$ increased compared to shams. Concentrations in other major organs did not differ from sham-exposed mice.

\section{Animal weight gain}

We observed a body weight loss in mice (average of $2 \mathrm{~g}$ ) after the first week of exposure in the sub-chronic $\mathrm{ZnO}$ NP study (Figure 5). This drop was not observed in the sub-acute study, in which mice gained $0.6 \mathrm{~g}$ after the first week of exposure. Animals exposed to laboratory air and sentinels gained $0.8 \mathrm{~g}$ and $0.9 \mathrm{~g}$, respectively.

\section{Evaluation of BAL fluid and hematology parameters Sub-acute study}

The number of total cells in BAL fluid (Table 3) was significantly $(p<0.01)$ increased in mice exposed to $\mathrm{ZnO}$ NPs and necropsied at 0 wk post exposure (150.3 \pm 14.9 $\times 10^{3}$ cells/mouse) as compared to control mice (92.7 \pm $8.6 \times 10^{3}$ cells/mouse). Similarly, as shown in Figure 6A, the number of macrophages $\left(144.3 \pm 11.8 \times 10^{3}\right.$ cells/ mouse) was significantly $(p<0.01)$ increased compared to shams $\left(92.5 \pm 8.6 \times 10^{3}\right.$ cells/mouse). Mice necropsied at $0 \mathrm{wk}$ post exposure had significantly higher $(p<0.02)$ recruitment of neutrophils $\left(2.6 \pm 0.7 \times 10^{3}\right.$ cells/mouse $)$ as compared to shams $\left(0.1 \pm 0.07 \times 10^{3}\right.$ cells/mouse $)$. However, the proportion of neutrophils among total cells was only $1.7 \%$ in mice necropsied at $0 \mathrm{wk}$.

Concentrations of total protein analyzed in BAL fluid were not different between $\mathrm{ZnO} \mathrm{NP}$-exposed groups and

Table $2 \mathrm{Zn}$ concentration in BAL fluid and organs of shams and ZnO NP-exposed mice determined by ICP-MS

\begin{tabular}{|c|c|c|c|c|c|c|}
\hline \multirow{3}{*}{ Zn concentration } & \multicolumn{3}{|c|}{ Sub-acute study } & \multicolumn{3}{|c|}{ Sub-chronic study } \\
\hline & \multicolumn{3}{|c|}{ Experimental group: } & \multicolumn{3}{|c|}{ Experimental group: } \\
\hline & $\begin{array}{l}\text { Shams } \\
(n=6)\end{array}$ & $\begin{array}{c}\text { ZnO } 0 \text { wk } \\
(n=7)\end{array}$ & $\begin{array}{c}\mathrm{ZnO} 3 \text { wks } \\
(\mathrm{n}=6)\end{array}$ & $\begin{array}{l}\text { Shams } \\
(n=6)\end{array}$ & $\begin{array}{c}\mathrm{ZnO} 0 \mathrm{wk} \\
(\mathrm{n}=8)\end{array}$ & $\begin{array}{c}\text { ZnO } 3 \text { wks } \\
(n=6)\end{array}$ \\
\hline$\overline{B A L}$ fluid, $\mu \mathrm{g} / \mathrm{L} \#$ & $16 \pm 2$ & $73 \pm 9^{* * *}$ & $16 \pm 2$ & $48 \pm 10$ & $80 \pm 23$ & $42 \pm 1$ \\
\hline Blood, $\mu \mathrm{g} / \mathrm{L}$ & $4800 \pm 123$ & $4650 \pm 131$ & $4840 \pm 157$ & $5117 \pm 189$ & $5567 \pm 42$ & $4950 \pm 250 \# \#$ \\
\hline Lung, $\mu \mathrm{g} / \mathrm{g}$ (dry wt) & $123.3 \pm 2.6$ & $144.8 \pm 6.9^{* *}$ & $131.4 \pm 13.7$ & $109.7 \pm 8.8$ & $102.1 \pm 4.4$ & $109.6 \pm 4.3$ \\
\hline Heart, $\mu \mathrm{g} / \mathrm{g}$ (dry wt) & $121.8 \pm 2.7$ & $127.8 \pm 6.0$ & $112.6 \pm 10.1$ & $115.4 \pm 4.4$ & $150.9 \pm 14.7^{*}$ & $124.1 \pm 7.0$ \\
\hline Liver, $\mu g / g$ (dry wt) & $155.5 \pm 5.5$ & $161.3 \pm 4.4$ & $153.2 \pm 10.4$ & $100.2 \pm 5.3$ & $111.2 \pm 6.0$ & $108.9 \pm 8.4$ \\
\hline Spleen, $\mu \mathrm{g} / \mathrm{g}$ (dry wt) & $108.6 \pm 2.5$ & $114.6 \pm 4.2$ & $111.6 \pm 3.9$ & $164.9 \pm 33.6$ & $277.6 \pm 46.2$ & $156.0 \pm 23.3$ \\
\hline Kidney, $\mu \mathrm{g} / \mathrm{g}$ (dry wt) & $97.8 \pm 8.4$ & $88.0 \pm 4.0$ & $85.9 \pm 5.8$ & $96.8 \pm 7.9$ & $110.8 \pm 9.9$ & $97.2 \pm 7.0$ \\
\hline Brain, $\mu \mathrm{g} / \mathrm{g}$ (dry wt) & $101.7 \pm 4.4$ & $102.7 \pm 4.1$ & $104.7 \pm 4.1$ & $47.9 \pm 3.6$ & $43.6 \pm 2.6$ & $43.6 \pm 2.7$ \\
\hline
\end{tabular}

Values are expressed as mean and $\mathrm{SE} ;{ }^{*} p<0.05,{ }^{* *} p<0.05,{ }^{* *} p<0.001$ significantly increased from shams.

\# BAL was not digested, $\mathrm{Zn}$ concentration represents mainly dissolved $\mathrm{Zn}$ ions in BAL fluid.

$\# \#=3$. 


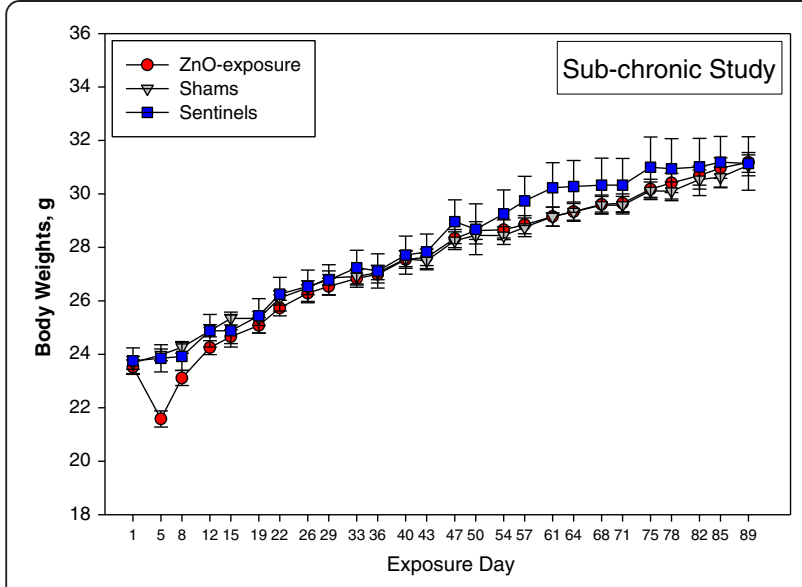

Figure 5 Body weights of animals during sub-chronic exposure to ZnO NPs. There was a significant decline in the body weights of mice on day 5 of ZnO NP exposure, compared to controls or sentinels.

controls. The activity of LDH was not different between mice necropsied at $0 \mathrm{wk}$ and shams but was significantly higher 3 wks post exposure $(p<0.01$, Table 3$)$.

Only 2 of the 7 measured inflammatory cytokines/chemokines were significantly elevated at 0 wk post exposure, IL-12p(40) and MIP- $1 \alpha(\mathrm{p}<0.05$ and $\mathrm{p}<0.01$, respectively). These concentrations were increased 1.6- and 1.3fold from levels in sham-exposed mice (Figure 7A). Hematology parameters were evaluated to assess if exposure to ZnO NPs caused any systemic inflammatory changes (Table 4). We found no significant differences between $\mathrm{ZnO}$ NP-exposed mice and shams, with the exception of hematocrit that was significantly higher in mice exposed to ZnO NPs and necropsied 3 wks post exposure compared to shams ( $52.7 \%$ vs. $47.7 \%$, respectively).

\section{Sub-chronic study}

There was a significant enhancement in the recruitment of cells to the lungs after sub-chronic exposure to $\mathrm{ZnO}$ NPs compared to sham-exposed mice. Mice euthanized immediately after the last $\mathrm{ZnO} \mathrm{NP}$ exposure had a 2 -fold higher number of cells in BAL fluid than shams
(Table 5). This increased cellularity was represented mainly by macrophages, and there were no significant increases in numbers of neutrophils or lymphocytes between $\mathrm{ZnO} \mathrm{NP}$-exposed mice and their sham-exposed counterparts (Figure 6B). The concentration of total protein and activity of LDH in BAL fluid were not different between $\mathrm{ZnO}$ NP-exposed mice and their controls (Table 6). In the sub-chronic study we also measured the concentration of MDA in homogenates of lung tissue as a marker of ROS generation and found no significant difference between exposed and control mice. Whole blood parameters did not show any sign of systemic inflammatory response (Table 6). Similarly like in subacute study, hematocrit in mice exposed for 13 wks sacrificed at 3 wks post exposure was increased. Cytokine/chemokine concentrations in BAL fluid for the subchronic study are shown in Figure 7B. The results show no significant differences in $\mathrm{ZnO}$ NP-exposed groups and shams. The concentrations of IL- 4 and IL-5 were below lowest limit of detection $(2.20 \mathrm{pg} / \mathrm{mL}$ and 5.38 $\mathrm{pg} / \mathrm{mL}$, respectively).

\section{Lung histopathology in sub-acute and sub-chronic study}

Since a preliminary bright field microscopy screening of lung tissues with H\&E staining showed a lack of evidence for overt lesions, a more sensitive scale for the detection of changes in pathologic parameters (inflammation, cell injury, fibrosis, congestion and possible eosinophila) was imposed. Due to application of this 4-point scale $(0$ - no lesion, 1 - minor focal change $[<10 \%$ of lung], 2 - multifocal to coalescing inflammation [11-50\%], and 3 - widespread $>50 \%$ ), even the control animals showed presence of many evaluated histology parameters, indicating that the extent of lesions found in exposed animals was not due to $\mathrm{ZnO} \mathrm{NP}$ exposure. In both, the sub-acute and sub-chronic study, there were a few lungs that showed a slight increase in number of macrophages and/or with occasional evidence of alveolar macrophage activation (slightly foamy cytoplasm, karyomegaly, binucleate, and mitotic figures). In addition to these changes, rare minor foci of perivascular lymphoid cells and/or focal septal hypercellularity were found in

Table 3 Total number of cells, total protein concentration and activity of LDH in BAL fluid in shams and ZnO NP-exposed mice (sub-acute study)

\begin{tabular}{|c|c|c|c|c|}
\hline \multirow{2}{*}{$\begin{array}{l}\text { Sub-acute study } \\
\text { Parameter in BAL fluid }\end{array}$} & \multirow[b]{2}{*}{$\begin{array}{l}\text { Sentinels } \\
(n=2)\end{array}$} & \multicolumn{3}{|c|}{ Experimental group: } \\
\hline & & $\begin{array}{l}\text { Shams } \\
0 \text { wk } \\
(n=6)\end{array}$ & $\begin{array}{l}\mathrm{ZnO} \\
0 \mathrm{wk} \\
(\mathrm{n}=6)\end{array}$ & $\begin{array}{l}\mathrm{ZnO} \\
3 \mathrm{wks} \\
(\mathrm{n}=6)\end{array}$ \\
\hline Total cells/mouse, $\mathrm{n} \times 10^{3}$ & $105.0 \pm 27.0$ & $92.7 \pm 8.6$ & $150.3 \pm 14.9^{* *}$ & $67.0 \pm 11.2$ \\
\hline Total protein, $\mu \mathrm{g} / \mathrm{mL}$ & $122.2 \pm 2.9$ & $135.5 \pm 6.8$ & $125.5 \pm 4.1$ & $131.3 \pm 5.8$ \\
\hline LDH activity, U/L & $63 \pm 18$ & $46 \pm 4$ & $32 \pm 9$ & $93 \pm 23^{* *}$ \\
\hline
\end{tabular}

Values are expressed as mean and $\mathrm{SE}^{* *} p<0.01$ significantly different from sham-exposed animals (one way ANOVA). 


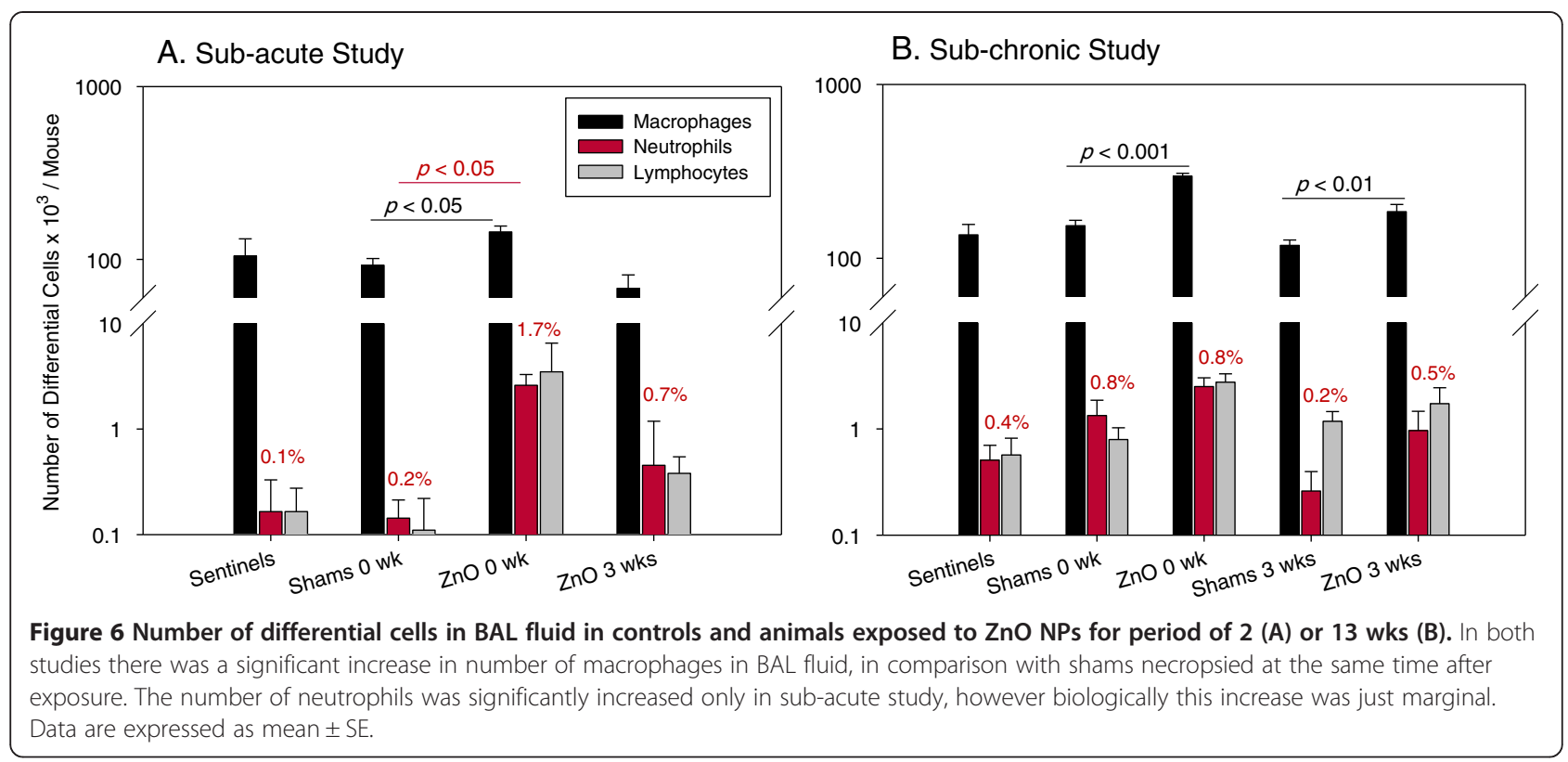

sub-chronic study mice. There was a distinct lack of cell injury, fibrosis or eosinophil infiltration in mice from either study. In the few sites with hypercellularity of the alveolar septa, there were occasional granulocytes partially sequestered in the septa composed of both neutrophils and eosinophils, however these were just marginal inside of sticky capillaries due to minor focal activation. Figure 8A shows the histopathology scores from the lung tissues. Most common minor changes found in lung tissues of controls or $\mathrm{ZnO} \mathrm{NP}$-exposed mice are shown in Figures 8B, C and D.

\section{Pulmonary mechanics measurements in sub-acute and} sub-chronic study

Measurements of pulmonary mechanics involving resistance and compliance without cholinergic agonist showed no difference between mice exposed to $\mathrm{ZnO}$ NPs and shams-exposed mice (Figure 9). Treatment with escalating doses of methacholine showed no evidence of hyperreactive airways due to exposure to $\mathrm{ZnO} \mathrm{NPs}$. For comparison, positive control mice treated with bleomycin via intra-tracheal instillation (to induce transient fibrosis) or mice sensitized and challenged with house

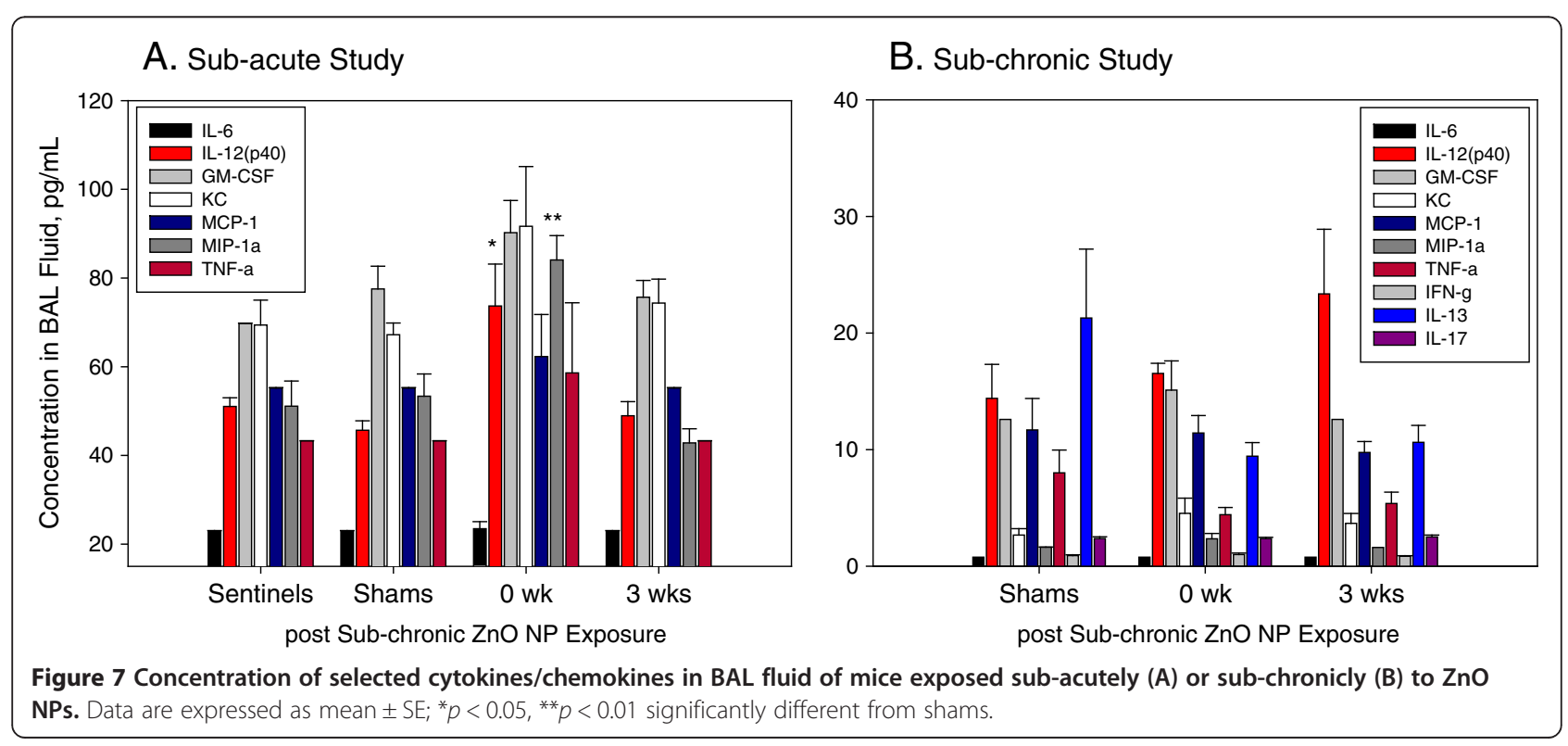


Table 4 Blood parameters in shams and mice after sub-acute exposure to ZnO NPs

\begin{tabular}{lccc}
\hline Sub-acute study & \multicolumn{3}{c}{ Experimental group: } \\
\cline { 2 - 4 } Whole blood parameter & Shams & ZnO 0 wk & ZnO 3 wks \\
\hline WBC $\times 10^{3} / \mu \mathrm{L}$ & $2.91 \pm 0.9$ & $2.81 \pm 0.3$ & $3.11 \pm 0.4$ \\
$\mathrm{RBC} \times 10^{6} / \mu \mathrm{L}$ & $9.85 \pm 0.3$ & $10.27 \pm 0.5$ & $9.49 \pm 0.2$ \\
Hemoglobin, $\mathrm{g} / \mathrm{dL}$ & $16.5 \pm 0.4$ & $17.3 \pm 0.6$ & $15.3 \pm 0.2$ \\
Hematocrit,\% & $47.7 \pm 1.3$ & $51.3 \pm 2.0$ & $52.7 \pm 1.1^{* *}$ \\
Monocytes $\times 10^{3} / \mu \mathrm{L}$ & $0.33 \pm 0.1$ & $0.33 \pm 0.0$ & $0.39 \pm 0.1$ \\
Neutrophils $\times 10^{3} / \mu \mathrm{L}$ & $0.56 \pm 0.1$ & $0.38 \pm 0.1$ & $0.84 \pm 0.1$ \\
Lymphocytes $\times 10^{3} / \mu \mathrm{L}$ & $1.95 \pm 0.7$ & $2.02 \pm 0.3$ & $1.83 \pm 0.3$ \\
Eosinophils $\times 10^{3} / \mu \mathrm{L}$ & $0.052 \pm 0.016$ & $0.052 \pm 0.016$ & $0.082 \pm 0.019$ \\
Basophils $\times 10^{3} / \mu \mathrm{L}$ & $0.014 \pm 0.008$ & $0.022 \pm 0.009$ & $0.018 \pm 0.007$
\end{tabular}

Values are expressed as mean and $\mathrm{SE}, \mathrm{WBC}$ - white blood cells, RBC - red blood cells; ${ }^{* *} p<0.02$ (significantly different from shams), $n=6$ in each group.

dust mite allergen (Dermatophagoides pteronyssinus, Der p 2) demonstrated increasing resistance and decreasing compliance with increasing doses of inhaled methacholine. We conclude that inhalation exposure to $\mathrm{ZnO}$ NPs for period of 2 or 13 wks did not cause clinically significant remodeling of the airway in mice nor did it induce hyperreactive airways.

\section{Discussion}

Our studies assessed toxicological effects of $\mathrm{ZnO}$ NPs in mice following sub-acute (2-wk) and sub-chronic (13-wk) inhalation exposure. Nanoparticles were fully characterized prior to and during exposures. Geometric mean mobility diameter of $\mathrm{ZnO} \mathrm{NP}$ aerosol sampled from the whole-body chamber was $46 \mathrm{~nm}$ and $36 \mathrm{~nm}$ in sub-acute and sub-chronic study, respectively and demonstrated a moderate degree of aggregation.

The bioavailability and toxicity of metal oxide nanoparticles are often related to the ability of the nanoparticles to deliver soluble metal ions to the adjacent tissues [22]. Nanoparticles often have enhanced dissolution kinetics due to their larger surface area in comparison with bulk material [23]. Additionally, the extent of dissolution can be size dependent [23]. Multiple studies have shown that $\mathrm{ZnO}$ NPs dissolve in the acidic environment of the phagolysosomes [22,26]. Here, we observed ligandpromoted dissolution [39] facilitated by citrate ligands used in ALF solution to represent a coordinating moiety that might be found in protein binding as well (Figure 3). Our data suggest that $\mathrm{ZnO}$ NPs dissolved in the lung (Table 2). Concentration of $\mathrm{Zn}^{2+}$ in the supernatants of BAL fluid was 4.5-fold higher in mice necropsied immediately after the exposure than in shams or mice necropsied 3 wks post exposure (Table 2). For the sub-chronic study (Table 2), the increase of $\mathrm{Zn}^{2+}$ ions in BAL fluid from shams was lower, the concentration was only 2 -fold higher than in shams or mice at 3 wks post exposure. However, this increase was not statistically significant $(p=0.065)$. Interestingly, in the sub-chronic study, we did not find any increase in $\mathrm{Zn}$ in the lungs of mice sacrificed at $0 \mathrm{wk}$ in comparison with controls. Evaluation of BAL cells and lung tissues using dark field microscopy as well as TEM-EDS did not show a distinct presence of $\mathrm{Zn}$ NPs inside the macrophages or lung tissues (data not shown). The blood $\mathrm{Zn}$ concentrations were slightly elevated in mice at $0 \mathrm{wk}$ in sub-chronic study, but not in sub-acute study. Since we have used a whole-body exposure chamber in our studies, it is possible that some portion of $\mathrm{ZnO}$ particles was ingested and transferred to the blood through the gastrointestinal system. None of the other organs analyzed in either study had significantly elevated $\mathrm{Zn}$ concentrations. Wang et al. performed an acute instillation study in Wistar rats in which a bolus of $2.5 \mathrm{mg} / \mathrm{kg} \mathrm{ZnO}$ NPs was delivered by a dry powder sprayer directly into nasal passages, twice daily for 3 days (total dose $15 \mathrm{mg} / \mathrm{kg}$ ) [10]. Doses in our studies were lower with $2.0 \mathrm{mg} / \mathrm{kg}$ delivered in 14 days (sub-acute) and $10.9 \mathrm{mg} / \mathrm{kg}$ delivered in 89 days (sub-chronic). Even at this high dose, Wang et al. found no significant differences in $\mathrm{Zn}$ content in lungs compared to controls, $\mathrm{Zn}$ levels were significantly

Table 5 Total number of cells, total protein concentration and activity of LDH in BAL fluid and MDA concentration in the lungs in shams and ZnO NP-exposed mice (sub-chronic study)

\begin{tabular}{|c|c|c|c|c|c|}
\hline \multirow[t]{2}{*}{ Sub-chronic study } & \multirow[b]{2}{*}{ Sentinels } & \multicolumn{4}{|c|}{ Experimental group: } \\
\hline & & $\begin{array}{c}\text { Shams } \\
0 \mathrm{wk}\end{array}$ & $\begin{array}{l}\mathrm{ZnO} \\
0 \mathrm{wk}\end{array}$ & $\begin{array}{l}\text { Shams } \\
3 \text { wks }\end{array}$ & $\begin{array}{c}\mathrm{ZnO} \\
3 \text { wks }\end{array}$ \\
\hline \multicolumn{6}{|c|}{ Parameter in BAL fluid $(n=6)$ : } \\
\hline Total cells/mouse, $\mathrm{n} \times 10^{3}$ & $137.3 \pm 20.5$ & $156.0 \pm 11.8$ & $302.0 \pm 11.5^{* * *}$ & $116.3 \pm 8.3$ & $188.0 \pm 19.3^{* *}$ \\
\hline Total protein, $\mu \mathrm{g} / \mathrm{mL}$ & $101.7 \pm 3.0$ & $101.8 \pm 2.4$ & $108.4 \pm 5.5$ & $117.5 \pm 16.2$ & $123.8 \pm 6.6$ \\
\hline LDH activity, U/L & $106.0 \pm 19.5$ & $60.8 \pm 14.6$ & $74.7 \pm 12.7$ & $95.3 \pm 12.1$ & $83.7 \pm 14.5$ \\
\hline \multicolumn{6}{|l|}{ Parameter in Lung $(n=6)$ : } \\
\hline MDA concentration, $\mathrm{nmol} / \mathrm{mL}$ & NA & $50.0 \pm 2.5$ & $58.7 \pm 6.8$ & NA & NA \\
\hline
\end{tabular}

Values are expressed as mean and $\mathrm{SE} ;{ }^{* * *} p<0.001,{ }^{* *} p<0.01$ significantly different from control counterparts (one way ANOVA followed by Tukey test); NA not analyzed. 
Table 6 Blood parameters in shams and mice after sub-chronic exposure to ZnO NPs

\begin{tabular}{lcccc}
\hline Whole blood & & \multicolumn{3}{c}{ Experimental group: } \\
\cline { 2 - 5 } parameter & Sentinels & Shams 0 wk & ZnO 0 wk & ZnO $\mathbf{~ w k s}$ \\
\hline WBC $\times 10^{3} / \mu \mathrm{L}$ & $3.62 \pm 0.5$ & $4.18 \pm 0.6$ & $3.79 \pm 1.0$ & $4.90 \pm 0.4$ \\
$\mathrm{RBC} \times 10^{6} / \mu \mathrm{L}$ & $9.66 \pm 0.2$ & $9.20 \pm 0.2$ & $9.6 \pm 0.4$ & $9.63 \pm 0.3$ \\
Hemoglobin, $\mathrm{g} / \mathrm{dL}$ & $15.4 \pm 0.2$ & $16.0 \pm 0.2$ & $16.2 \pm 0.4$ & $16.2 \pm 0.2$ \\
Hematocrit, $\%$ & $50.2 \pm 0.7$ & $45.0 \pm 0.6$ & $47.8 \pm 0.3$ & $52.9 \pm 1.7$ \\
Monocytes $\times 10^{3} / \mu \mathrm{L}$ & $0.34 \pm 0.1$ & $0.22 \pm 0.1$ & $0.24 \pm 0.1$ & $0.20 \pm 0.3$ \\
Neutrophils $\times 10^{3} / \mu \mathrm{L}$ & $2.11 \pm 0.5$ & $0.92 \pm 0.2$ & $1.29 \pm 0.3$ & $1.9 \pm 0.2$ \\
Lymphocytes $\times 10^{3} / \mu \mathrm{L}$ & $1.14 \pm 0.2$ & $2.98 \pm 0.4$ & $2.20 \pm 0.9$ & $2.75 \pm 0.4$ \\
Eosinophils $\times 10^{3} / \mu \mathrm{L}$ & $0.032 \pm 0.010$ & $0.055 \pm 0.013$ & $0.062 \pm 0.035$ & $0.074 \pm 0.013$ \\
Basophils $\times 10^{3} / \mathrm{\mu L}$ & $0.002 \pm 0.001$ & $0.013 \pm 0.003$ & $0.013 \pm 0.004$ & $0.008 \pm 0.003$ \\
\hline Vatues a & &
\end{tabular}

Values are expressed as mean and SE, WBC - white blood cells, RBC - red blood cells, $n=6$ in each group.

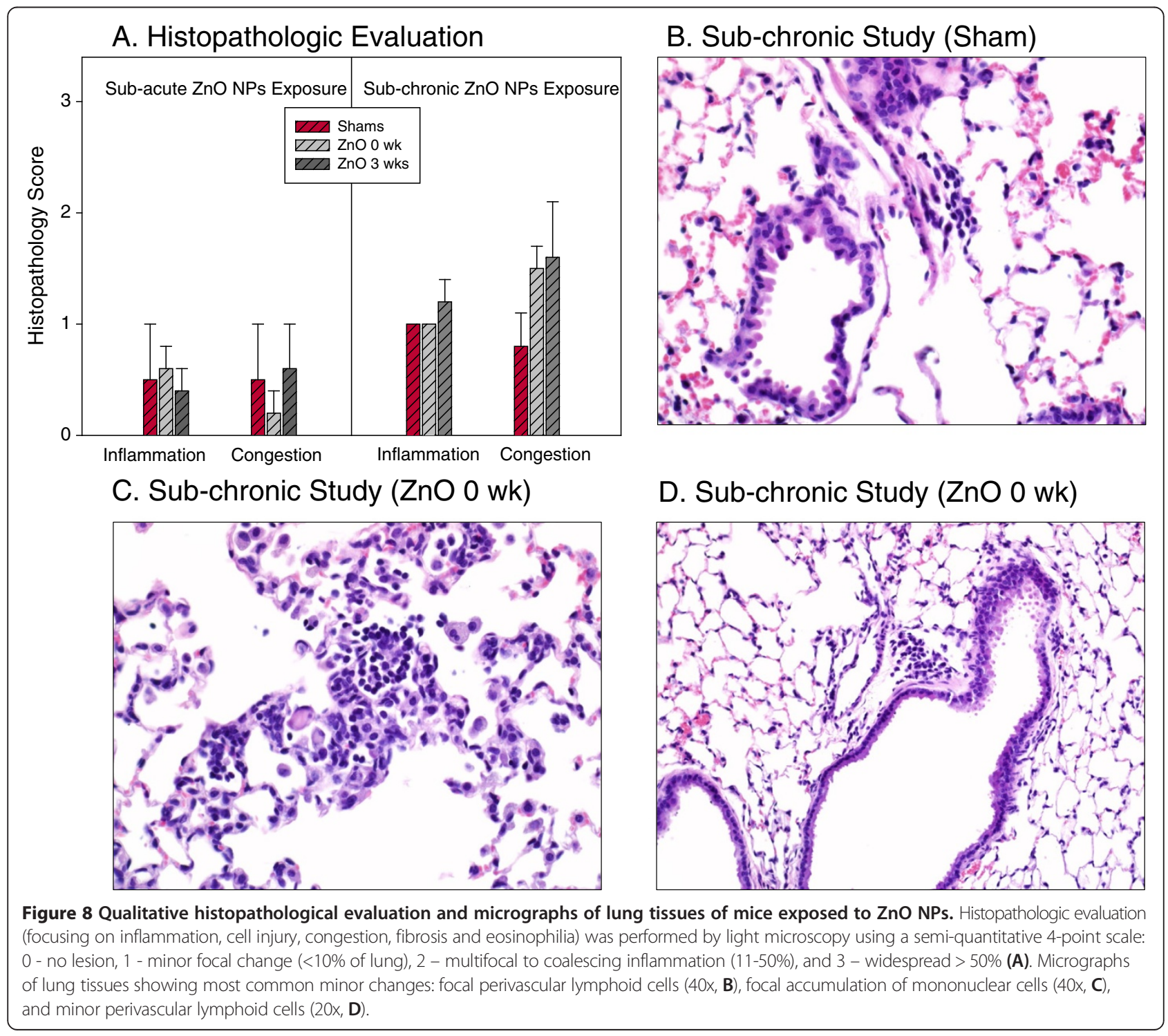



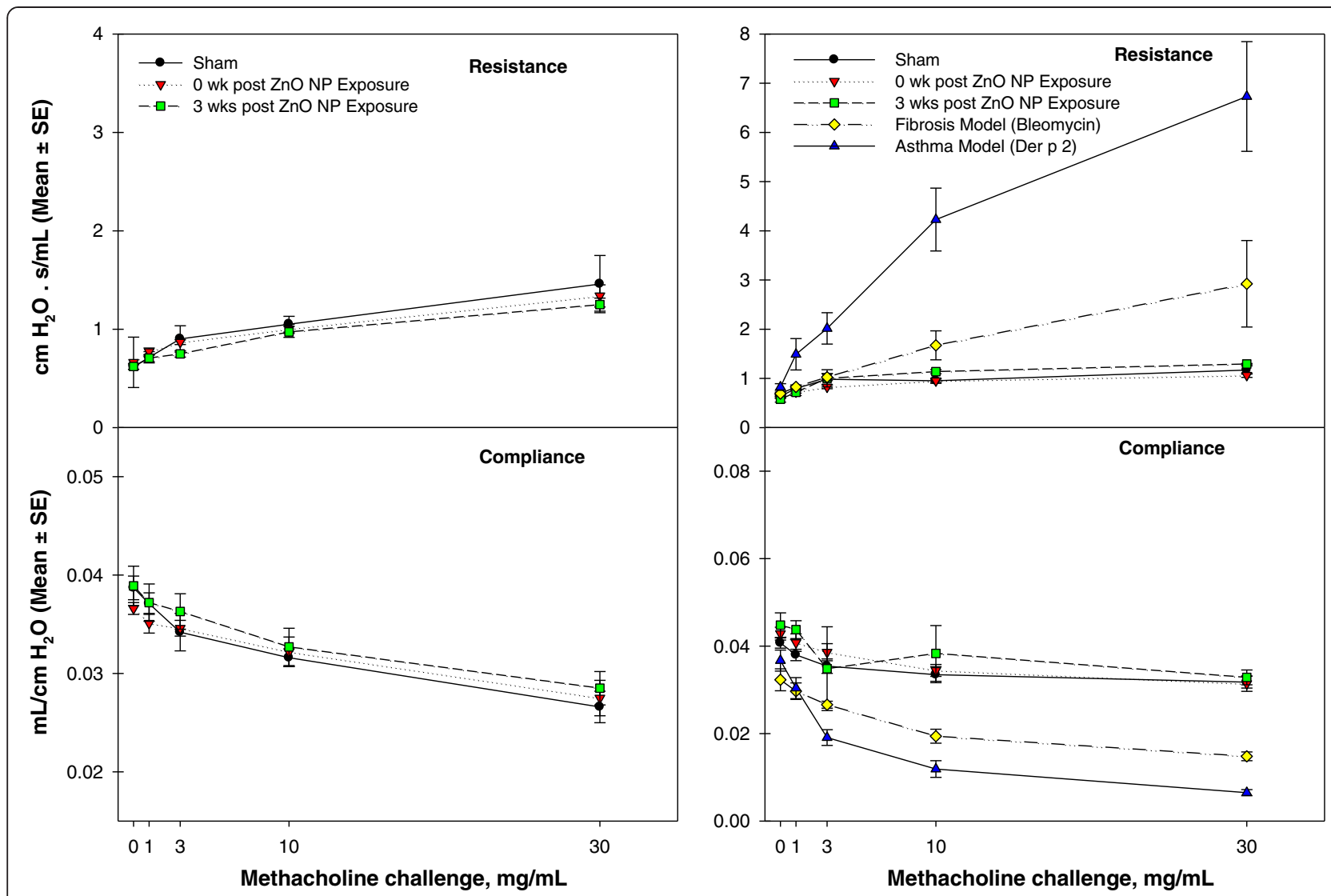

Figure 9 Results of pulmonary mechanics measurements of mice after sub-acute (A) or sub-chronic (B) exposure to ZnO NPs or filtered laboratory air (sham). Resistance and compliance were measured after inhalation challenge to increasing concentration of methacholine (1, 3, 10, and $30 \mathrm{mg} / \mathrm{mL}$ ). Plot B also shows resistance and compliance in positive control mice exposed by nasal instillation to bleomycin (fibrosis model) or house dust mite allergen (Dermatophagoides pteronyssinus, asthma model). No changes in pulmonary mechanics were observed in mice exposed to ZnO NPs for 2 (A) or 13 wks (B).

increased in livers at $12 \mathrm{hr}$ and $36 \mathrm{hr}$ time point and in kidneys at $36 \mathrm{hr}$ time point. Furthermore, they reported that exposure caused inflammation, interstitial hyperemia, emphysema and hyperplasia in the lungs and serious hepatic lesions. These data further suggest that $\mathrm{ZnO} \mathrm{NPs}$ dissolve in the lungs or translocate to the blood for circulation. Intravenously administered $\mathrm{ZnO}$ NPs exhibited a primary retention in lung for the first hour and were excreted via intestines into feces within 24. $\mathrm{h}$ [40]. Such fast elimination of $\mathrm{ZnO}$ NPs from the system might be attributed to a high dissolution of these particles in biological fluids with lower $\mathrm{pH}$ as shown in Figure 3. The NIEHS Nano GO Consortium found $\mathrm{ZnO}$ NPs to be the most cytotoxic in in vitro studies (out of three forms of $\mathrm{TiO}_{2}$, and three forms of multiwalled carbon nanotubes [MWCNTs] [41]. Unfortunately, $\mathrm{ZnO}$ NPs were not included in their in vivo interlaboratory evaluation and hence provide no basis for comparison with this study [42].

$\mathrm{ZnO}$ dissolution is relevant to pulmonary toxicity due to inhalation exposure to $\mathrm{ZnO}$ in the welding fumes in occupational settings [43] as well as for use of $\mathrm{ZnO}$ as a raw material in manufacturing. Inhalation of ultrafine $\mathrm{ZnO}$ was found to be the major cause of zinc fume fever that is characterized by increased neutrophils in BAL fluid, along with an increase in TNF- $\alpha$, IL-1, and IL-8, followed by decreased lung function, cough, fever, and metallic taste [43]. The National Institute for Occupational Safety and Health (NIOSH) has established a recommended exposure limit for $\mathrm{ZnO}$ of $5 \mathrm{mg} / \mathrm{m}^{3}$ as a time-weighted average concentration for up to a 10-hr workday and a 40-hr workweek. The estimated doses of $\mathrm{ZnO}$ NPs in tracheobronchial and pulmonary region of mouse were $51 \mu \mathrm{g} / \mathrm{mouse}(2.0 \mathrm{mg} / \mathrm{kg})$ in the sub-acute and $306 \mu \mathrm{g} /$ mouse $(10.9 \mathrm{mg} / \mathrm{kg})$ in the sub-chronic study. These estimated doses correspond to the lung dose accumulated by a $70 \mathrm{~kg}$ person exposed to a concentration of $5 \mathrm{mg} / \mathrm{m}^{3}$ for 13 or 71 workdays (assuming breathing frequency 15 breaths $/ \mathrm{min}, 600 \mathrm{~mL} / \mathrm{breath}$, and pulmonary deposition fraction for $40 \mathrm{~nm}$ particles of 0.5 [31].

Our previous toxicity studies of copper, iron or silver NPs $[28,29,44]$ are in agreement with "the higher 
solubility - the higher toxicity effect" [11,45]; however $\mathrm{ZnO}$ NPs despite very high solubility in acidic milieu that contain coordinating ligands demonstrated minimal toxicity in our inhalation studies. Of the many pulmonary biomarkers measured, we observed biologically significant increase only in total number of cells in BAL fluid mainly due to an increase in macrophages and a moderate increase in IL-12(p40) and MIP- $1 \alpha$ in BAL fluid. Measurements of a cytototoxicity biomarker (activity of LDH) in BAL fluid showed a significant increase in mice sacrificed at 3 wks post sub-chronic exposure compared to controls. ROS in the lungs (assessed via MDA) were not different in $\mathrm{ZnO} \mathrm{NP}$-exposed mice and controls. Histopathology evaluation of lung tissues as well as pulmonary mechanics measurements revealed no significant changes from controls. There were no eosinophils and few neutrophils found in BAL fluid or lung tissue in mice after inhalation exposure to ZnO NPs in sub-acute or sub-chronic exposure. Furthermore, the concentrations of IL-4, IL-5, IL-13 and IL-17 in BAL fluid were not elevated after exposure to ZnO NPs. Our results are contrary to data reported by Cho et al. $[8,26,46]$. Intratracheal instillation of ZnO NPs at a surface area dose of 50 or $150 \mathrm{~cm}^{2} /$ rat (corresponding to a mass of $0.5 \mathrm{mg}$ / $\mathrm{kg}$ or $1.4 \mathrm{mg} / \mathrm{kg}$, respectively) caused eosinophilia, proliferation of airway epithelial cells, goblet cell hyperplasia, and pulmonary fibrosis. This eosinophilic response in BAL fluid was not reproduced in mice $(\mathrm{C} 57 \mathrm{Bl} / 6$ and $\mathrm{BALB} / \mathrm{c}$ ) after an aspiration of $\mathrm{ZnO}$ NPs dispersed in $5 \%$ heat-inactivated mouse serum $\left(15 \mathrm{~cm}^{2} /\right.$ mouse or $1.2 \mathrm{mg} /$ $\mathrm{kg}$ ), but these authors reported that the concentration of eotaxin and IL-13 in the BAL fluid was significantly increased at $24 \mathrm{hr}$ post exposure compared to controls [26]. Later studies by this group found that recruitment of eosinophils was initiated by metal oxide nanoparticles themselves not their soluble ions [46]. To assess this discrepancy, we exposed mice to $\mathrm{ZnO}$ NPs by intra-tracheal instillation ( $4 \mathrm{mg} / \mathrm{kg}$ or $47 \mathrm{~cm}^{2} /$ mouse) with necropsy $24 \mathrm{hr}$ after the exposure and found a higher recruitment of neutrophils (40\%) in BAL fluid (data not shown) than in shams $(2 \%)$ in which no eosinophils were found. The recruitment of neutrophils to the lungs in case of instillation exposure might be a part of an acute inflammatory response to a different exposure method (instillation $v s$. inhalation). Our studies confirm that $\mathrm{ZnO}$ NPs have very modest inflammatory potency in vivo after repeated inhalation exposures but one time instillation exposure of a bolus dose of NPs caused an inflammatory response. These results support the notion that in vitro $\mathrm{ZnO} \mathrm{NP}$ studies in submersed condition may produce false-positive results due to a higher dissolution of ZnO NPs in media without further translocation and clearance. Furthermore, Cho et al. [26] observed that large poorly dispersed agglomerates of $\mathrm{ZnO}$ NPs induced lower eosinophilia (1\%) compared to well-dispersed ZnO NPs (38\%) and hypothesized that eosinophilic inflammation might be induced only by well dispersed $\mathrm{ZnO}$ NPs at high doses. We suggest that inhalation studies at environmentally relevant doses represent more realistic exposures to $\mathrm{ZnO} \mathrm{NP}$ aerosols.

In our studies, we found a significant but modest increase in IL-12(p40) as well as MIP-1 $\alpha$ compared to controls after sub-acute exposure to $\mathrm{ZnO}$ NPs. Both cytokines are released by activated macrophages [47]. Histopathology evaluation of lung tissues showed a moderate presence of slightly foamy alveolar macrophages in mice exposed to ZnO NPs necropsied immediately post exposure. On the other hand, this finding might be important for a possible use of ZnO NPs in an anti-cancer treatment. It was reported that ZnO NPs induce release of the proinflammatory cytokines (IL-12, IFN- $\gamma$, and TNF- $\alpha$ ) without major cytotoxicity effects [48] and our studies support this potential use.

Development of clinical tolerance to repeated inhalation exposure to $\mathrm{ZnO}$ fumes from welding processes has been reported in clinical studies of metal fume fever [5] as well as in a study of zinc foundry workers [49] and a studies of $\mathrm{ZnO}$ fumes in mice [6,50]. Symptoms of metal fume fever usually dissipate within $24-48 \mathrm{hr}$ without major lung injury $[43,49]$. It is possible that repeated inhalation exposure to ZnO NPs at low exposure concentrations may lead to the attenuation of pulmonary responses. In our sub-chronic study, we observed a decrease in body weight of animals after first 5 days of exposure to ZnO NPs (Figure 5) which might be a clinical sign of initial response to ZnO NPs that was later diminished with repeated exposures. In the pulmonary tolerance study [6], NIH-Swiss mice were exposed to $1 \mathrm{mg} / \mathrm{m}^{3} \mathrm{ZnO}$ for 1,3 , or 5 days, mice acquired tolerance to neutrophil recruitment to the lungs, however tolerance to total protein in BAL fluid was not observed suggesting persistence of lung injury. Furthermore, a greater lung pathology was found in mice exposed repeatedly to $\mathrm{ZnO}$ compared to the ones exposed one time. Development of pulmonary tolerance to repeated exposure of inhaled toxicants is not fully understood and more studies are necessary to confirm this phenomenon.

\section{Conclusions}

The results of in vitro and in vivo studies of ZnO NP toxicity have been contradictory and thus controversial. Our sub-acute (2-wk-) and sub-chronic (13-wk-) whole-body inhalation exposure studies with average $\mathrm{ZnO} \mathrm{NP}$ concentration of $3.5 \mathrm{mg} / \mathrm{m}^{3}$ induced a significant increase in recruitment of total white blood cells to the lungs that was represented mainly by increased macrophages and a moderate increase of IL-12 (p40) and MIP-1 $\alpha$. None of the other inflammatory pulmonary markers measured in BAL fluid or lungs, histopathology evaluation or changes in 
pulmonary mechanics after methacholine challenge were significantly different from sham-exposed controls. We observed slightly elevated hematocrit values at $3 \mathrm{wks}$ post exposure in both sub-acute and sub-chronic exposure. Our study suggests a high dissolution of ZnO NPs in lung tissues and translocation of $\mathrm{Zn}$ to the blood circulation. Furthermore, our study shows that the higher dissolution of metal-based nanomaterials is not necessarily associated with higher toxicity upon inhalation exposure as seen here for $\mathrm{ZnO}$.

\section{Abbreviations}

Ag: Silver; ALF: Artificial lysosomal fluid; ANOVA: Analyses of variance; AMTIR: Amorphous material transmitting infrared radiation; ATR: Attenuated total reflectance; BAL: Bronchoalveolar lavage; C: Dynamic Compliance; $\mathrm{CeO}_{2}$ : Cerium dioxide; Derp: Dermatophagoides pteronyssinus; EDS: Energy dispersive spectrometer; FTIR: Fourier transform infrared; GM: Geometric mean; GM-CSF: Granulocyte macrophage colony stimulating factor; GSD: Geometric standard deviation; H \& E: Hematoxylin and eosin; HEPA: High-efficiency particulate air; ICP-OES: Inductively coupled plasma - optical emission spectroscopy; IL: Interleukin; IFN: Interferon; KC: Keratinocyte-derived cytokine; LDH: Lactate dehydrogenase; MCP: Monocyte chemotactic protein; MDA: Malondialdehyde; MIP: Macrophage inflammatory protein; NIOSH: National Institute for Occupational Safety and Health; NIEHS: National Institute of Health Sciences; ICP-MS: Inductively coupled plasma-mass spectrometry; MWCNTs: Multiwalled carbon nanotubes; NPs: Nanoparticles; R: Dynamic resistance; RAW 264.7: Mouse leukemic monocyte macrophage; ROS: Reactive oxygen species; SMPS: Scanning mobility particle sizer; TBARS: Thiobarbituric acid reactive substances; TEM: Transmission electron microscopy; $\mathrm{TiO}_{2}$ : Titanium dioxide; TNF: Tumor necrosis factor; XPS: X-ray photoelectron spectroscopy; XRD: Powder X-ray diffraction; ZnO: Zinc oxide.

\section{Competing interests}

The authors (AA-D, LVS, JSK, SUV, APA, PTO, VHG and PST) report no competing interests.

\begin{abstract}
Authors' contributions
AA-D designed animal studies, conducted animal exposures, biological assays, pulmonary mechanics measurements and analyses, elemental analyses in mouse tissues, processed particle size distribution data, data analysis, and drafted the manuscript. LVS performed nanomaterial characterization, dissolution studies, elemental analyses, and assisted with manuscript drafting. JSK participated in the study design, conducted animal exposures, necropsies and biological assays. SUV assisted with animal exposures, necropsies and biological assays in the sub-acute study. APA assisted with nanomaterial characterization. PTO developed and coordinated the aerosol generation system for inhalation exposures and characterized exposure concentrations and aerosol size distribution. VHG initiated the integrated study design, led analyses of nanomaterial characterization and dissolution data, authored portions of the manuscript and edited the final manuscript. PST designed the animal studies, coordinated the biological assays and data analysis, and authored the final manuscript. All authors read and approved the final manuscript.
\end{abstract}

\section{Acknowledgements}

This study was supported by NIOSH (National Institutes of Occupational Safety and Health) grant R01 OH009448 and NIEHS grant P30 ES005605. We thank Ralph Altmaier, MS for his help setting up the aerosol generation and exposure system; David Meyerholz, DVM, PhD for histopathology evaluation of lung tissues; David Peate, PhD for assistance with ICP-MS measurements; Jonas Baltrusaitis, PhD for XPS, HRTEM and TEM-EDS measurements; and Jean Ross for sample preparation for TEM-EDS. The Sysmex XE-2100 automatic hematology analyzer used in this study was generously provided by Sysmex Corporation, Kobe, Japan.

\section{Author details}

${ }^{1}$ Department of Occupational and Environmental Health, University of lowa, lowa City, IA 52242, USA. ²Department of Chemistry, University of lowa, lowa City, IA 52242, USA.

Received: 14 October 2013 Accepted: 7 March 2014 Published: 1 April 2014

\section{References}

1. Project on Emerging Nanotechnologies (PEN): A Nanotechnology Consumer Products Inventory; 2010. http://www.nanotechproject.org/cpi/ Woodrow Wilson International Center for Scholars.

2. Osmond MJ, McCall MJ: Zinc oxide nanoparticles in modern sunscreens: an analysis of potential exposure and hazard. Nanotoxicology 2010, 4:15-41.

3. Becheri A, Durr M, Lo Nostro P, Baglioni P: Synthesis and characterization of zinc oxide nanoparticles: application to textiles as UV-absorbers. J Nanopart Res 2008, 10:679-689.

4. Burnett ME, Wang SQ: Current sunscreen controversies: a critical review. Photodermatol Photoimmunol Photomed 2011, 27:58-67.

5. Fine JM, Gordon T, Chen LC, Kinney P, Falcone G, Sparer J, Beckett WS: Characterization of clinical tolerance to inhaled zinc oxide in naive subjects and sheet metal workers. J Occup Environ Med 2000, 42:1085-1091.

6. Wesselkamper SC, Chen LC, Gordon T: Development of pulmonary tolerance in mice exposed to zinc oxide fumes. Toxicol Sci 2001 60:144-151.

7. Zhang $\mathrm{H}$, Chen $\mathrm{B}$, Jiang $\mathrm{H}$, Wang $\mathrm{C}$, Wang $\mathrm{H}$, Wang $\mathrm{X}$ : A strategy for $\mathrm{ZnO}$ nanorod mediated multi-mode cancer treatment. Biomaterials 2011, 32:1906-1914.

8. Cho WS, Duffin R, Poland CA, Howie SEM, MacNee W, Bradley M, Megson IL, Donaldson K: Metal oxide nanoparticles induce unique inflammatory footprints in the lung: important implications for nanoparticle testing. Environ Health Perspect 2010, 118:1699-1706.

9. Wang B, Feng WY, Wang M, Wang TC, Gu YQ, Zhu MT, Ouyang H, Shi JW, Zhang F, Zhao YL, Zhao YL, Chai ZF, Wang HF, Wang J: Acute toxicological impact of nano- and submicro-scaled zinc oxide powder on healthy adult mice. J Nanopart Res 2008, 10:263-276.

10. Wang LJ, Wang L, Ding WJ, Zhang F: Acute toxicity of ferric oxide and zinc oxide nanoparticles in rats. J Nanosci Nanotechnol 2010, 10:8617-8624.

11. Xia TA, Zhao Y, Sager T, George S, Pokhrel S, Li N, Schoenfeld D, Meng HA, Lin SJ, Wang X, Wang MY, Ji ZX, Zink JI, Madler L, Castranova V, Lin S, Nel AE: Decreased dissolution of $\mathrm{ZnO}$ by iron doping yields nanoparticles with reduced toxicity in the rodent lung and zebrafish embryos. Acs Nano 2011, 5:1223-1235.

12. Sayes $C M$, Reed $K L$, Warheit DB: Assessing toxicity of fine and nanoparticles: comparing in vitro measurements to in vivo pulmonary toxicity profiles. Toxicol Sci 2007, 97:163-180.

13. Lu S, Duffin R, Poland C, Daly P, Murphy F, Drost E, Macnee W, Stone V, Donaldson K: Efficacy of simple short-term in vitro assays for predicting the potential of metal oxide nanoparticles to cause pulmonary inflammation. Environ Health Perspect 2009, 117:241-247.

14. Hackenberg S, Scherzed A, Technau A, Kessler M, Froelich K, Ginzkey C, Koehler C, Burghartz M, Hagen R, Kleinsasser N: Cytotoxic, genotoxic and pro-inflammatory effects of zinc oxide nanoparticles in human nasal mucosa cells in vitro. Toxicol Vitro 2011, 25:657-663.

15. Yang H, Liu C, Yang DF, Zhang HS, Xi ZG: Comparative study of cytotoxicity, oxidative stress and genotoxicity induced by four typical nanomaterials: the role of particle size, shape and composition. J Appl Toxicol 2009, 29:69-78.

16. Lin WS, Xu Y, Huang CC, Ma YF, Shannon KB, Chen DR, Huang YW: Toxicity of nano- and micro-sized $\mathrm{ZnO}$ particles in human lung epithelial cells. J Nanopart Res 2009, 11:25-39.

17. Kasemets K, Ivask A, Dubourguier HC, Kahru A: Toxicity of nanoparticles of $\mathrm{ZnO}, \mathrm{CuO}$ and $\mathrm{TiO} 2$ to yeast Saccharomyces cerevisiae. Toxicol Vitro 2009, 23:1116-1122.

18. Dimkpa CO, Calder A, Britt DW, McLean JE, Anderson AJ: Responses of a soil bacterium, pseudomonas chlororaphis $\mathrm{O6}$ to commercial metal oxide nanoparticles compared with responses to metal ions. Environ Pollut (Oxford, UK) 2011, 159:1749-1756. 
19. Hooper HL, Jurkschat K, Morgan AJ, Bailey J, Lawlor AJ, Spurgeon DJ Svendsen C: Comparative chronic toxicity of nanoparticulate and ionic zinc to the earthworm Eisenia veneta in a soil matrix. Environ Int 2011 37:1111-1117.

20. Xie Y, Williams NG, Tolic A, Chrisler WB, Teeguarden JG, Maddux BL, Pounds JG, Laskin A, Orr G: Aerosolized ZnO nanoparticles induce toxicity in alveolar type II epithelial cells at the air-liquid interface. Toxicol Sci 2012, 125:450-461.

21. Lenz AG, Karg E, Brendel E, Hinze-Heyn H, Maier KL, Eickelberg O, Stoeger T, Schmid O: Inflammatory and oxidative stress responses of an alveolar epithelial cell line to airborne zinc oxide nanoparticles at the air-liquid interface: a comparison with conventional, submerged cell-culture conditions. Biomed Res Int 2013, 2013:652632.

22. Xia T, Kovochich $M$, Liong M, Madler L, Gilbert B, Shi HB, Yeh Jl, Zink Jl, Nel AE: Comparison of the mechanism of toxicity of zinc oxide and cerium oxide nanoparticles based on dissolution and oxidative stress properties. Acs Nano 2008, 2:2121-2134.

23. Mudunkotuwa IA, Rupasinghe T, Wu CM, Grassian VH: Dissolution of ZnO nanoparticles at circumneutral $\mathrm{pH}$ : a study of size effects in the presence and absence of citric acid. Langmuir 2012, 28:396-403.

24. Kim JS, Peters TM, O'Shaughnessy PT, Adamcakova-Dodd A, Thorne PS: Validation of an in vitro exposure system for toxicity assessment of air-delivered nanomaterials. Toxicol Vitro 2013, 27:164-173.

25. Ho M, Wu KY, Chein HM, Chen LC, Cheng TJ: Pulmonary toxicity of inhaled nanoscale and fine zinc oxide particles: mass and surface area as an exposure metric. Inhal Toxicol 2011, 23:947-956.

26. Cho WS, Duffin R, Howie SE, Scotton CJ, Wallace WA, Macnee W, Bradley M, Megson IL, Donaldson K: Progressive severe lung injury by zinc oxide nanoparticles; the role of $\mathrm{Zn} 2+$ dissolution inside lysosomes. Part Fibre Toxicol 2011, 8:27.

27. Baltrusaitis J, Usher $C R$, Grassian VH: Reactions of sulfur dioxide on calcium carbonate single crystal and particle surfaces at the adsorbed water carbonate interface. Phys Chem Chem Phys 2007, 9:3011-3024.

28. Stebounova LV, Adamcakova-Dodd A, Kim JS, Park H, O'Shaughnessy PT, Grassian VH, Thorne PS: Nanosilver induces minimal lung toxicity or inflammation in a subacute murine inhalation model. Part Fibre Toxicol 2011, 8:5.

29. Kim JS, Adamcakova-Dodd A, O'Shaughnessy PT, Grassian VH, Thorne PS: Effects of copper nanoparticle exposure on host defense in a murine pulmonary infection model. Part Fibre Toxicol 2011, 8:29.

30. Adamcakova-Dodd A, Stebounova LV, O'Shaughnessy PT, Kim JS, Grassian $\mathrm{VH}$, Thorne PS: Murine pulmonary responses after sub-chronic exposure to aluminum oxide-based nanowhiskers. Part Fibre Toxicol 2012, 9:22.

31. Cassee FR, Freijer Jl, Subramaniam R, Asgharian B, Miller FJ, van Bree L, Rombout PJA: Development of a model for human and rat aimay particle deposition: implications for risk assessment. RIVM Report 650010018. Bilthoven, the Netherlands: Dutch National Institute of Public Health and Environment (RIVM); 1999.

32. O'Shaughnessy PT, Achutan C, O'Neill ME, Thorne PS: A small whole-body exposure chamber for laboratory use. Inhal Toxicol 2003, 15:251-263.

33. Taurozzi JS, Hackley VA, Wiesner MR: Ultrasonic dispersion of nanoparticles for environmental, health and safety assessment-issues and recommendations. Nanotoxicology 2011, 5:711-729.

34. Guo ZH, Wei SY, Shedd B, Scaffaro R, Pereira T, Hahn HT: Particle surface engineering effect on the mechanical, optical and photoluminescent properties of ZnO/vinyl-ester resin nanocomposites. J Mater Chem 2007, 17:806-813.

35. Bian SW, Mudunkotuwa IA, Rupasinghe T, Grassian VH: Aggregation and dissolution of $4 \mathrm{~nm} \mathrm{ZnO}$ nanoparticles in aqueous environments: influence of $\mathrm{pH}$, ionic strength, size, and adsorption of humic acid. Langmuir 2011, 27:6059-6068.

36. Yang M, Marino MJ, Bojan VJ, Eryilmaz OL, Erdemir A, Kim SH: Quantification of oxygenated species on a diamond-like carbon (DLC) surface. App/ Surf Sci 2011, 257:7633-7638.

37. Profatilova IA, Kim SS, Choi NS: Enhanced thermal properties of the solid electrolyte interphase formed on graphite in an electrolyte with fluoroethylene carbonate. Electrochim Acta 2009, 54:4445-4450.

38. Nel AE, Madler L, Velegol D, Xia T, Hoek EM, Somasundaran P, Klaessig F, Castranova $V$, Thompson M: Understanding biophysicochemical interactions at the nano-bio interface. Nat Mater 2009, 8:543-557.

39. Kraemer $\mathrm{SM}$, Chiu VQ, Hering JG: Influence of $\mathrm{pH}$ and competitive adsorption on the kinetics of ligand-promoted dissolution of aluminum oxide. Environ Sci Tech 1998, 32:2876-2882.
40. Chen JK, Shih MH, Peir JJ, Liu CH, Chou FI, Lai WH, Chang LW, Lin P, Wang MY, Yang MH, Yang CS: The use of radioactive zinc oxide nanoparticles in determination of their tissue concentrations following intravenous administration in mice. Analyst 2010, 135:1742-1746.

41. Xia T, Hamilton RF, Bonner JC, Crandall ED, Elder A, Fazlollahi F, Girtsman TA, Kim K, Mitra S, Ntim SA, Orr G, Tagmount M, Taylor AJ, Telesca D, Tolic A, Vulpe CD, Walker AJ, Wang X, Witzmann FA, Wu N, Xie Y, Zink JI, Nel A, Holian A: Interlaboratory evaluation of in vitro cytotoxicity and inflammatory responses to engineered nanomaterials: the NIEHS Nano GO consortium. Environ Health Perspect 2013, 121:683-690.

42. Bonner JC, Silva RM, Taylor AJ, Brown JM, Hilderbrand SC, Castranova V, Porter D, Elder A, Oberdorster G, Harkema JR, Bramble LA, Kavanagh TJ, Botta D, Nel A, Pinkerton KE: Interlaboratory evaluation of rodent pulmonary responses to engineered nanomaterials: the NIEHS Nano GO consortium. Environ Health Perspect 2013, 121:676-682.

43. Brown JJ: Zinc Fume Fever. Br J Radiol 1988, 61:327-329.

44. Pettibone JM, Adamcakova-Dodd A, Thorne PS, O'Shaughnessy PT, Weydert JA, Grassian VH: Inflammatory response of mice following inhalation exposure to iron and copper nanoparticles. Nanotoxicology 2008, 2:189-204.

45. Nel A, Xia T, Meng H, Wang X, Lin S, Ji Z, Zhang H: Nanomaterial toxicity testing in the 21st century: use of a predictive toxicological approach and high-throughput screening. Acc Chem Res 2013, 46:607-621.

46. Cho WS, Duffin R, Poland CA, Duschl A, Oostingh GJ, Macnee W, Bradley M, Megson IL, Donaldson K: Differential pro-inflammatory effects of metal oxide nanoparticles and their soluble ions in vitro and in vivo; zinc and copper nanoparticles, but not their ions, recruit eosinophils to the lungs. Nanotoxicology 2012, 6:22-35.

47. Mosser DM, Edwards JP: Exploring the full spectrum of macrophage activation. Nat Rev Immunol 2008, 8:958-969.

48. Hanley C, Thurber A, Hanna C, Punnoose A, Zhang J, Wingett DG: The influences of cell type and $\mathrm{ZnO}$ nanoparticle size on immune cell cytotoxicity and cytokine induction. Nanoscale Res Lett 2009, 4:1409-1420.

49. Martin CJ, Le XC, Guidotti TL, Yalcin S, Chum E, Audette RJ, Liang C, Yuan B, Zhang $X$, Wu J: Zinc exposure in Chinese foundry workers. Am J Ind Med 1999, 35:574-580.

50. Wesselkamper SC, Chen LC, Kleeberger SR, Gordon T: Genetic variability in the development of pulmonary tolerance to inhaled pollutants in inbred mice. Am J Physiol Lung Cell Mol Physiol 2001, 281:L1200-L1209.

doi:10.1186/1743-8977-11-15

Cite this article as: Adamcakova-Dodd et al: Toxicity assessment of zinc oxide nanoparticles using sub-acute and sub-chronic murine inhalation models. Particle and Fibre Toxicology 2014 11:15

\section{Submit your next manuscript to BioMed Central and take full advantage of:}

- Convenient online submission

- Thorough peer review

- No space constraints or color figure charges

- Immediate publication on acceptance

- Inclusion in PubMed, CAS, Scopus and Google Scholar

- Research which is freely available for redistribution 